\title{
Compositional patterns of benthic assemblages on the northwestern Ross Sea shelf, Antarctica: interacting environmental drivers operating at multiple spatial scales
}

\author{
Ashley A. Rowden · Kerstin Kröger • \\ Malcolm R. Clark
}

Received: 19 October 2014/Revised: 15 April 2015/Accepted: 25 April 2015/Published online: 9 May 2015

(C) The Author(s) 2015. This article is published with open access at Springerlink.com

\begin{abstract}
A comprehensive study of mega- and macro-invertebrate benthic assemblages was conducted on the northwestern Ross Sea shelf in 2004 in order to examine concurrently the energy-, disturbance-, and habitat heterogeneity-diversity hypotheses, and their relevance for identifying the environmental drivers that structure benthic assemblages in Antarctica. Five transects were sampled, each of which was divided into 3 depth strata $(50-250,250-500,500-750 \mathrm{~m})$, running perpendicular to the Victoria Land coast between Cape Adare in the north and Cape Hallett in the south. The influence of environmental variables acting on different spatial scales on benthic assemblages was assessed, including primary productivity (large-scale), iceberg scouring (quantified on different spatial scales), and habitat heterogeneity (small-
\end{abstract}

Guest editors: Diego Fontaneto \& Stefano Schiaparelli / Biology of the Ross Sea and Surrounding Areas in Antarctica

Electronic supplementary material The online version of this article (doi:10.1007/s10750-015-2305-2) contains supplementary material, which is available to authorized users.

A. A. Rowden $(\bowtie) \cdot$ K. Kröger · M. R. Clark National Institute of Water \& Atmospheric Research, Private Bag 14-901, Wellington 6241, New Zealand e-mail: a.rowden@niwa.co.nz

Present Address:

K. Kröger

Joint Nature Conservation Committee, Inverdee House, Baxter Street, Aberdeen AB11 9QA, UK scale). Clear geographic gradients could not be established for the environmental variables or for the invertebrate assemblages, but there were strong depthrelated differences in the composition of assemblages. Overall, the results suggest that a combination, and interaction, of large-scale oceanographic (i.e. surface chlorophyll $a$, seasonal ice cover) and local habitat (e.g. sediment sponge spicule content) variables are responsible for the patterns of benthic invertebrate assemblage composition observed in the northwestern Ross Sea.

Keywords BioRoss $\cdot$ Iceberg disturbance $\cdot$ Habitat heterogeneity $\cdot$ Large-scale $\cdot$ Productivity $\cdot$ Smallscale $\cdot$ Sponge spicules

\section{Introduction}

The relationship between the spatial distribution of benthic invertebrate assemblages and the environment wherein they reside or associate with has been the subject of numerous studies around the globe. Antarctic-wide examinations of the distributional patterns of benthic invertebrate assemblages (multiple-taxa as opposed to single taxon assemblages) have not often been possible, owing to the paucity of complete taxonomic sampling or identification (see review by Arntz et al., 1994). However, some regions of the Antarctic shelf have received intensive and 
widespread sampling where whole macro-invertebrate assemblages have been identified and described; most notable among these large-scale surveys are those conducted along the 2,250 km shelf of the Weddell and Lazarev Seas (Galéron et al., 1992; Gerdes et al., 1992; Gutt \& Starmans, 1998). Such studies have allowed for consideration of how certain "environmental drivers" may influence invertebrate assemblages of the shelf. Gutt (2000), with reference to the benthic assemblages of that region, systematically examined the collective evidence for the structuring role of a number of factors. He concluded that it was difficult to disentangle the relative importance of a number of environmental variables and that further quantitative investigations were required.

Benthic assemblages of continental shelves can be modified by human activities, even in Antarctica (e.g. hydrocarbon/PCB/metal pollution at McMurdo Station, see Lenihan \& Oliver, 1995), and threats exist as a consequence of increased tourist boat traffic, bottom longline fishing, and increased temperatures from global warming and acidification from $\mathrm{CO}_{2}$ uptake (Clarke \& Harris, 2003; Barnes \& Peck, 2008). Understandably, calls have been forthcoming to set aside marine protected areas of sufficient size to fulfil conservation objectives. However, appropriate selection of such areas depends on adequate knowledge of biodiversity (Gallardo, 1987). Within New Zealand's Ross Dependency, the Ross Sea shelf faces current and potential threats (e.g. toothfish fishery and tourism). Already in 2002 (the year before the study reported here was initiated), the establishment of protected areas had been suggested (Bradford-Grieve \& Fenwick, 2002), and the results of several more recent surveys have been used to develop a proposal for the establishment of a 'Ross Sea Region Marine Protected Area' to be put forward to the Commission for the Conservation of Antarctic Marine Resources (CCAMLAR) (https://www.ccamlr.org/en/ccamlr-xxxii/27).

\section{Ross Sea shelf}

The Ross Sea is atypical for Antarctica in having a wide continental shelf with a relatively deep shelf break (ca. $800 \mathrm{~m}$ ), while off most other parts of the continent the shelf is narrow or virtually absent (Gallardo, 1987). Apart from some early sporadic sampling by expeditions of discovery and exploration, the first extensive and systematic surveys of benthic fauna of the shelf were carried out by the New Zealand Oceanographic Institute (NZOI) between 1958 and 1960 (Bullivant, 1967a). Prior to 2002, there existed a poor appreciation of the large-scale composition and distribution of invertebrate assemblages on the Ross Sea shelf, relative to that obtained for the shelf on the opposite side of Antarctica (i.e. Weddell/Lazarev Sea, Gutt \& Starmans, 1998). Consequently, the invertebrate assemblages identified by Bullivant (1967b) were effectively the reigning benthic 'community' model for the area at the time the present study was conceived. Furthermore, there was no concurrent examination of the environmental variables associated with the patterns observed by Bullivant, and so it was not possible to understand clearly the reasons for distribution of the assemblages.

\section{The BioRoss survey}

Whilst a number of reasons have been suggested for the distribution of invertebrates of the Ross Sea shelf (Bullivant, 1967b), no formal testing of any hypothesis thought to account for the region's benthic biodiversity patterns had been forthcoming until the advent of a number of national and international scientific programmes which began in the early twenty-first century. One of these endeavours was New Zealand's "BioRoss" programme, which began around the same time, and had links with the international "Latitudinal Gradient Project" (Howard-Williams et al., 2006). As part of the BioRoss programme, a quantitative study of the biodiversity of selected marine communities of the Ross Sea region was undertaken in 2004 (hereafter called the BioRoss Survey) and examined a number of hypotheses.

\section{Hypotheses}

Answering the question as to why assemblages are distributed heterogeneously has long been an objective for ecologists. Understanding why is a prerequisite to making recommendations about gaps in knowledge, vulnerability, and areas and communities that could be the subject of future research (Currie et al., 1999). Many hypotheses have been proposed to account for the distribution patterns of faunal assemblages, and the following main diversity hypotheses were examined during the BioRoss Survey. The (i) "energy-diversity hypothesis", (ii) the "disturbance- 
diversity hypothesis", (iii) and the "habitat heterogeneity-diversity hypothesis" (see Rosenzweig, 1995). While species richness is the component of diversity most often considered during examinations of these hypotheses, the BioRoss Survey focused on another component of diversity - variation in the composition of benthic assemblages. At the time of the present study's initiation, the following information was used to provide an Antarctic context for the study hypotheses and to predict the likely influence of productivity, iceberg disturbance, and biogenic habitat on the benthic assemblages of the northwestern Ross Sea shelf.

(i) In Antarctica, the flow of organic matter from the pelagic domain to the seabed represents an important energy source for benthic organisms (Grebmeier \& Barry, 1991; Gutt et al., 1998). The waters of the Ross Sea display spatial and temporal variations in primary productivity (Arrigo et al., 1998) that could therefore have an influence on invertebrate assemblage composition on the seabed. However, it is likely that the extent and duration of ice cover, and bottom currents will influence the arrival and distribution of the organic phytodetritus derived from surface primary production (e.g. Barry \& Dayton, 1988; Cattaneo-Vietti et al., 1999), and thereby moderate the expected pelagic-benthic coupling relationship. Therefore, we predicted that variation in the composition of benthic assemblages on the Ross Sea shelf would be related to large-scale (including presumed latitudinal) patterns in the deposition of organic matter on the seafloor derived from surface primary production. However, because sea ice cover and bottom current speed are implicated in affecting the distribution patterns of organic matter deposition to the seafloor, we predicted that intermediate and large-scale variation in assemblage composition would be related also to these variables.

(ii) For the invertebrate assemblages of Antarctic continental shelves, the most influential natural disturbance is scour from drifting icebergs (Gutt, 2000). Ice scour has generally been thought to influence shallow coastal areas of the Ross Sea (Dayton et al., 1970), but significant ice scour has been observed (via acoustic image data) offshore in the northwest region Ross Sea shelf (Mitchell, 2001). Ice scour (at $300 \mathrm{~m}$ ) in the Weddell Sea was shown to be associated with relatively impoverished benthic fauna assemblages (Gutt et al., 1996). Therefore, we predicted that variation in benthic assemblage composition would be related to large-scale distribution patterns of iceberg scour on the Ross Sea shelf, as well as potentially smaller-scale patterns of iceberg scour intensity.

(iii) In Antarctic shelf environments, where benthic faunal assemblages dominated by relatively large habitat-forming epifauna are particularly common, significant positive relationships between the number of species and the abundance of two 'types' of sponges have been shown (Gutt \& Starmans, 1998). Other organisms such as bryozoans and gorgonians are thought, like sponges, to play an important role in providing a suitable habitat for a considerable number of fauna, explaining in part the local community composition and high species diversity observed in Antarctic waters (Gutt \& Schickan, 1998; Gutt, 2000). In the Ross Sea, evidence for the importance of the habitat provided by, in particular, sponges (and their spicules) for assemblage development has been forthcoming (Dayton et al., 1994; Cantone et al., 2000) since Bullivant (1967b) inferred the relevance of such structural fauna from bottom photographs of the region's shelf. Therefore, we predicted that variation in the composition of benthic assemblages on the Ross Sea shelf, particularly the epifaunal component, would be related to the occurrence of biogenic habitat on the seafloor provided by habitat-forming species such as sponges, bryozoans, and corals. In addition, we expected that variation in infaunal assemblage composition would at least in part be related to the distribution and abundance of sponge spicules in the sediment, and other measures of sediment habitat heterogeneity.

Since the BioRoss Survey was conceived and conducted, a number of papers have been published 
which report on various components of the Ross Sea fauna (e.g. macrozoobenthos: Rehm et al., 2006, 2011; isopods: Choudhury \& Brandt, 2007; molluscs: Ghinglione et al., 2013; hydroids: Pena Cantero et al., 2013; tanaids: Blazewicz-Paszkowycz \& Sicinski, 2014), including those that have already used a significant amount of data from the BioRoss Survey itself (echinoderms: De Domenico et al., 2006, molluscs: Schiaparelli et al., 2006, peracarid crustaceans: Rehm et al., 2007, polychaetes: Kröger \& Rowden, 2008). These publications for the Ross Sea include attempts to elucidate the environmental drivers of benthic faunal composition in the shallow (Cummings et al., 2006; Lohrer et al., 2013) and deep (Barry et al., 2003; Povero et al., 2006; Lörz et al., 2013) waters of the shelf. There are also available Ross Sea/Antarctic publications which deal with specific environmental drivers (e.g. iceberg disturbance: Gerdes et al., 2003; Gutt \& Piepenburg, 2003; Teixido et al., 2004; Potthoff et al., 2006; Jones et al., 2007; Smale et al., 2007, 2008; Gerdes et al., 2008); variation in primary productivity: Dayton et al., 2013; biogenic habitat: Pabis \& Sicinski, 2012; Gutt et al., 2013a, b), multiple drivers (e.g. Cummings et al., 2010; Post et al., 2010; Thrush et al., 2010; Pabis et al., 2011; Linse et al., 2013), or review and synthesize information on the general themes examined by the BioRoss Survey (e.g. Thrush et al., 2006; Barnes \& Conlan, 2007; Gutt, 2007; Teixidó et al., 2007; Thrush \& Cummings, 2011; Gutt et al., 2013a, b; Kaiser et al., 2013). Thus, the present results for our hypotheses testing can now be discussed with respect to a significantly wider understanding and context than was envisaged originally at the time of the study. In particular, we have compared the results of our study with the findings of the more recent studies to refine current thinking on the nature of the interaction between different environmental drivers in shaping the structure of benthic assemblages on the Ross Sea shelf.

\section{Methods}

The BioRoss study involved a field sampling phase which was designed specifically to test concurrently the main hypotheses, as well as consider the influence of other environmental variables on the composition of benthic assemblages on the northwestern Ross Sea.
Sampling was focused on macro- and mega-benthic invertebrates, and the collection of a wide range of in situ environmental data that could be related as directly as possible to the biological data. Field environmental data were supplemented with the later collation of remote-sensed and modelled data. Data resulting from the study were analysed primarily using multivariate statistical routines, which were used to either test formally the main hypotheses or to determine correlations that could suggest explanations for the observed patterns in assemblage composition.

Study area and sampling design

The study area comprised the shelf area of the northwestern Ross Sea between Cape Adare at ca. $70^{\circ} \mathrm{S}$ and Cape Hallett at ca. $72^{\circ} \mathrm{S}$. A stratified random design was selected to address directly two of the three hypotheses to be examined ('energy-diversity' and 'disturbance-diversity') at the appropriate spatial scales. Five nominal transects running across the shelf (perpendicular to the depth contours and generally aligned SW-NE) were sampled (Fig. 1). Transect "start" points (N to S, approximate length) were transect 1 (Cape Adare, $25 \mathrm{~km})$, transect $2\left(71^{\circ} 35^{\prime}\right.$, $45 \mathrm{~km}$ ), transect 3 (Cape McCormick, $40 \mathrm{~km}$ ), transect $4\left(72^{\circ} 05^{\prime}, 80 \mathrm{~km}\right.$ ), and transect 5 (Cape Hallett, $120 \mathrm{~km})$. Each transect was divided into three depth strata $(50-250,250-500,500-750 \mathrm{~m})$. The alongshelf (transects) distribution of sampling effort was to encompass a potential latitudinal difference in surface primary productivity (at the time of the study there were no robust data available to describe in detail this supposed gradient). The across-shelf depth strata designations were intended to encompass a difference in the quantity of iceberg scour, based upon multibeam mapping undertaken by a previous survey which revealed particularly prominent iceberg scour between depths of 200-400 m (Mitchell, 2001).

\section{Sample collection}

Each transect was mapped using the ship's swath multibeam to establish bathymetry and backscatter. Sampling was conducted on the return path along the transects. Random replicate sampling within each of the 3 depth strata was planned with 4 sampling stations assigned per stratum using random numbers to determine direction from which the tow should begin and to 
Fig. 1 Map of the northwestern Ross Sea showing BioRoss Survey area in which stations were sampled along five (numbered) transects. Blue areas indicate sea ice shelves. Multibeam swathed area marked in light grey. Sampling stations and their depth stratification indicated by different symbols: circle 50-250 m, triangle 250-500 m, square 500-750 m

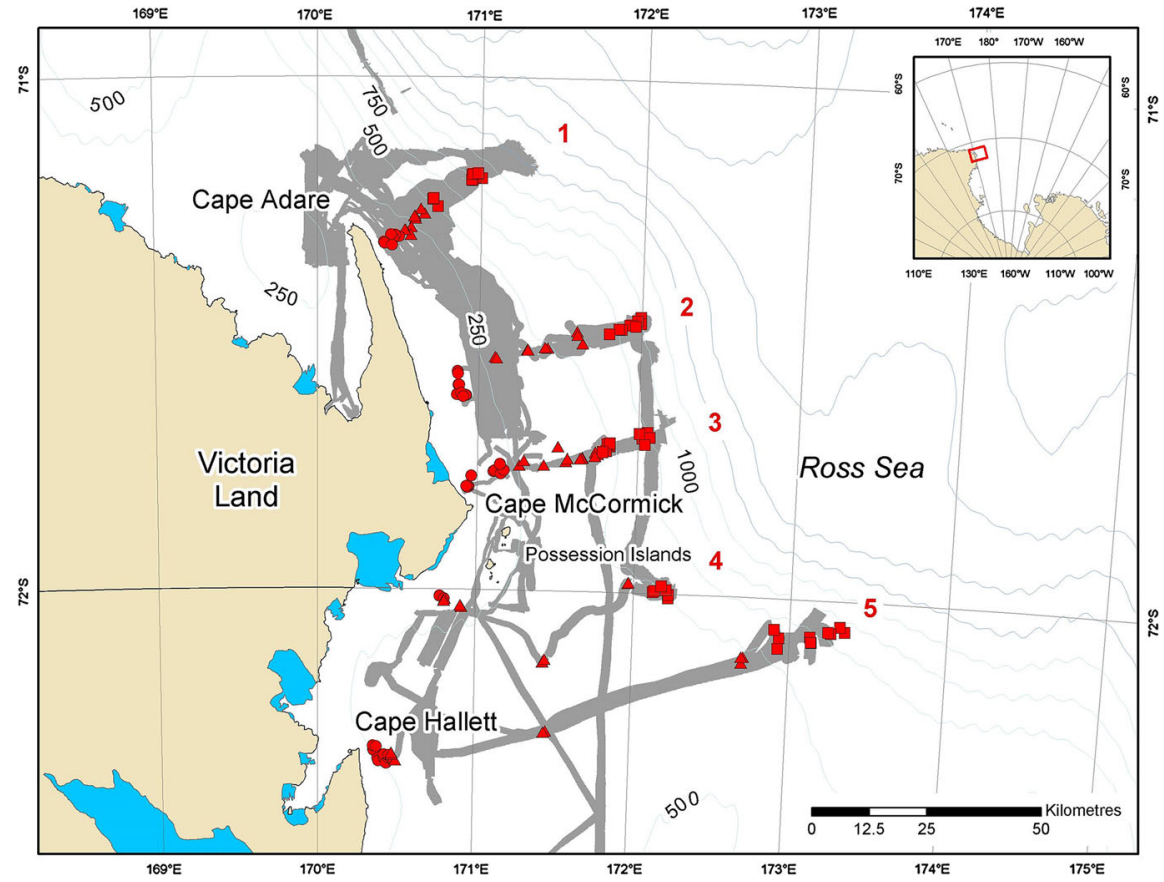

select a tow start depth. However, it was not always possible to obtain all replicates due to ice and/or weather conditions (Table 1).

A combination of gear types was employed to sample different components of the invertebrate assemblages present on and in the seabed. In order to sample mega-epifaunal invertebrates, an 'orange

Table 1 Number of samples per gear type, transect, and depth stratum

\begin{tabular}{lcccccc}
\hline $\begin{array}{l}\text { Gear } \\
\text { type }\end{array}$ & $\begin{array}{l}\text { Transect depth } \\
(\mathrm{m})\end{array}$ & 1 & 2 & 3 & 4 & 5 \\
\hline GVVL & $50-250$ & 3 & 3 & 4 & 1 & 4 \\
& $250-500$ & 3 & 5 & 4 & 4 & 4 \\
& $500-750$ & 4 & 3 & 4 & 3 & 4 \\
SEL & $50-250$ & 4 & 4 & 4 & 1 & 4 \\
& $250-500$ & 4 & 4 & 4 & 4 & 4 \\
& $500-750$ & 4 & 4 & 3 & 3 & 4 \\
ORH & $50-250$ & - & 1 & 4 & - & 3 \\
& $250-500$ & 2 & 3 & 3 & - & 2 \\
& $500-750$ & 3 & 1 & 4 & - & 3 \\
\hline
\end{tabular}

$G V V L$ van Veen grab, SEL epibenthic sled, $O R H$ 'orange roughy' wingless trawl, - no sample taken due to adverse ice and/or weather conditions roughy' wingless trawl (mouth opening $25 \times 8 \mathrm{~m}$, 40-mm-stretched mesh diameter in cod end) was employed. The trawl tow length was approximately 1 nautical mile, depending upon sampling rate and seafloor topography. An epibenthic sled (mouth opening $1.4 \times 0.5 \mathrm{~m}, 2 \mathrm{~m}$ long, 25 -mm-stretched mesh diameter) was employed to sample the macroepifauna. The sled was towed parallel to the depth contour at at target speed 1.5-2.0 knots (actual speed, 1-2.7 knots) and 15-min duration (actual tow length, $0.12-0.70 \mathrm{~nm}$ ). A van Veen grab (surface area $0.2 \mathrm{~m}^{2}$, volume 90 l) was employed to sample the macroinfaunal component of the benthos. In order to address the influence of environmental variables operating at small to intermediate spatial scales on the composition of benthic invertebrate assemblages, 4 separate sediment sub-samples (ca. $200 \mathrm{~g}$ ) were taken from the surface of each grab sample (through ports on the top of the grab using a cut-off syringe or small scoop if there was little sediment).

A video camera was mounted onto the frame of the grab in order to provide additional information about abundance/cover/morphology of species that generate structural habitat (such as sponges and corals) and the substratum characteristics. Two parallel lasers $(20 \mathrm{~cm}$ apart) were used to scale video images. 
Sample processing

Following retrieval of the sampling gear, the sample volume was recorded and the invertebrates recovered from the sled and trawl were sorted and identified onboard to the lowest possible taxonomic level and counted when appropriate. The contents of the grab were sieved on a $1-\mathrm{mm}$ mesh and then fixed in 5\% buffered formalin for post-voyage sorting and identification. Digital images of invertebrates sampled were taken to provide a visual record to aid later identification of specimens. Due to time constraints, sub-samples of unsorted material from the sampling were sometimes frozen for later processing. After sorting and identification onboard, the biological samples were either preserved in $80 \%$ ethanol, fixed in $5 \%$ buffered formalin, or frozen at $-20^{\circ} \mathrm{C}$. Postvoyage, invertebrate material was distributed to taxonomists or parataxonomists to confirm or improve the onboard identifications to the level of species or putative species. After identification, samples were transferred to $80 \%$ ethanol for storage at NIWA's Invertebrate Collection or institutes elsewhere.

Sub-samples of the video imagery from grab deployments were used to identify the visible fauna (typically of size $>0.5 \mathrm{~cm}$, Gutt \& Starmans, 1998) to the lowest possible taxonomic level and to determine their abundance. Sub-portion images $(50 \times 50 \mathrm{~cm})$ from the video, which were non-overlapping, of good quality (in-focus and sufficient illumination) and included the presence of both scaling laser marks, were selected in Ulead Video Studio 5 software before being imported into the image processing software ImageJ. Where possible, multiple images per station were analysed. Sedentary fauna (structural species) taxa were manually outlined with the freehand drawing tool, and the area covered by each "patch" (a distinct area of such fauna) was calculated by the software as a proportion of the sub-portion image. Substratum characteristics were similarly determined from the same sub-portion images, including the percentage cover of biogenic elements of the substratum ('broken barnacle shell', 'dead scleractinian coral', 'mixed broken shell/dead coral fragments', and 'mud burrows' - which were also counted). These variables were used to calculate an index of "Biological Habitat Complexity" (BHC) using the following formula:

$$
\frac{N \times \mathrm{CN}_{\mathrm{ST}}}{\mathrm{NP}}+\mathrm{CS}_{B},
$$

where $N$ is the mean number of 'patches' of structural taxa per image, $\mathrm{CN}_{\mathrm{ST}}$ is the total area (\%) covered by $N$ per image, NP is the total number of different patches per image, and $\mathrm{CS}_{B}$ is the mean area (\%) covered by biogenic substrate per image (Kröger \& Rowden, 2008).

Sediment sub-samples from the grab were taken for environmental determinations. These were transferred to labelled plastic bags and frozen at $-20^{\circ} \mathrm{C}$ for later analysis in the laboratory. The following variables were determined from the samples: sediment grain size distribution and sediment sponge spicule content (per $1 \mathrm{~g}$ sediment); sediment particulate organic carbon content (\% POC) and particulate nitrogen content ( $\% \mathrm{PN})$; and sediment surface phytodetritus (chlorophyll $a$ ) content (ng/mg).

In the laboratory, grain size analysis was conducted according to standard methods (Bale \& Kenny, 2005). Mean and median grain size and sorting coefficients were calculated using the indices of Folk \& Ward (1957). Sediment sponge spicule content was measured by counting the number of spicules in a $1 \mathrm{~g}$ sediment aliquot under a dissecting microscope using a 16-fold magnification. Sediment POC and PN were determined by following Method 01-1090 (Environment Canada, 1994). Almost all PN values were $<0.02 \%$ and thus were excluded from analysis. The method of Humphreys \& Jeffrey (1997) was used to extract chlorophyll $a$ from sediment sub-samples.

\section{Remotely sensed and modelled data}

Environmental variables that might influence the compositional patterns of invertebrate assemblages at intermediate to large spatial scales in the study area were also examined. Bottom water current information (maximum and mean speed) for the sampling stations was extracted from the Navy Coastal Ocean Model (NCOM) real time model runs for the period 1 January 2004 to 31 March 2004 (Rhodes et al., 2002). In many places, station spacing was less than the model resolution, and hence one set of model velocities was found for each cluster of stations (minimum distance between stations in any two different clusters was $2.2 \mathrm{~km}$ ). The position of each 
cluster was taken to be the mean of all the cluster members. The seabed velocities were then linearly interpolated to the cluster position.

SeaWIFS-derived surface water chlorophyll $a$ concentration data were obtained at a spatial resolution of approximately $9 \mathrm{~km}$ (http://oceancolor.gsfc.nasa.gov/ ftp.html). The chlorophyll data were composited into climatological means for each month (January-December) using an arithmetic average, and means for spring (September-November) and summer (December-February) periods were calculated from the monthly values. For the purpose of the present study, the chlorophyll concentrations were used as a proxy for primary production.

Sea ice distribution and cover data were obtained from the National Snow and Ice Data Centre (NSIDC), University of Colorado, Boulder, CO, USA (http:// nsidc.org). Mean ice concentration (percentage of grid cell covered by ice) for each month was averaged over the time period of the data set (November 1978 to December 2003) at a spatial resolution of about $25 \mathrm{~km}$. The annual and seasonal ice cover means were calculated from the monthly values for spring (September-November) and summer (December-February). Values for these seasons (rather than autumn and winter) were included in the analysis because of their likely stronger influence on the biological assemblages. Due to the relatively large size of the pixels used for ice cover data, those closest to the coast are likely to overlap sea and land ice and thus might slightly distort the sea ice cover values.

To quantify how much of the seafloor in the study area had been exposed to iceberg scouring, multibeam bathymetry data from the 5 transects were postprocessed using the Benthic Terrain Modeler v1.0 (BTM) software (http://www.csc.noaa.gov/ products/ $\mathrm{btm} /$ ) in ArcGIS. The Bathymetric Position Index (BPI) (Iampietro et al., 2005), was applied to a 25-m Digital Elevation Model (DEM), 'tuned' to detect troughs or depressions on the seafloor, and checked by eye. The result was a spatial data set indicating for each transect how much of the area was multibeamed (ice cover occasionally prevented multibeam operations) and the proportion of the multibeamed area that was scoured by icebergs. The dataset was used to create a set of statistics for each station. In the Weddell Sea, centres of ice scour disturbance are on average 750-2,000 m apart (Potthoff et al., 2006). Thus, for the present study, a radius of $1 \mathrm{~km}$ was created around each station and the number of iceberg scours within each radius was recorded as well as the $\%$ area scoured by icebergs (of the total area multibeamed within each radius-which was not always fully surveyed). An index of iceberg scour intensity was obtained by dividing the number of scours by the $\%$ area scoured for each radius (after Fig. 2 in Kröger \& Rowden, 2008). In order to include an assessment of disturbance by iceberg scour potentially operating on invertebrate assemblage composition at larger spatial scales, the distance from each station to the nearest scour (independent of the radius) was also measured. It was not possible to establish the age of the scours from the multibeam data; thus, scours are deemed for the purposes of the present study to represent a time-integrated measure of disturbance.

Data analysis

Differences among transects in mean surface chl $a$ summer and mean sediment chl $a$ were tested using ranked one-way ANOVA models (STATISTICA 8.0, StatSoft, Inc). The Shapiro Wilk $W$ test and Cochran's test were used to assess data assumptions of normal distribution and homoscedasticity, respectively. For multiple post hoc comparisons, Tukey's Honestly Significant Difference (HSD) test for unequal sample size was used.

The survey was not designed to sample benthic taxa such as algae, foraminiferans, nemerteans, and nematodes, or planktonic taxa such as medusae and copepods. Thus, all these taxa, when sampled, were excluded from the analyses.

Multivariate data analyses were undertaken using statistical routines (see below) in the software package PRIMER v 6.15 (Clarke \& Gorley, 2006). Prior to analysis, data were presence-absence transformed and similarity matrices were constructed for these data using the Bray-Curtis Index (Bray \& Curtis, 1957).

In order to test and examine the energy-, disturbance-, and habitat heterogeneity-diversity hypotheses, the following analyses were undertaken. A twoway crossed Analysis of Similarities (ANOSIM) (Clarke, 1993) was performed to test for significant differences in assemblage composition between the a priori sampling groups of transect and depth stratum. The null hypotheses tested were $\left(\mathrm{H}_{0} 1\right)$ no difference of assemblage composition among transects, allowing for differences among depth strata, and $\left(\mathrm{H}_{0} 2\right)$ no 
difference of assemblage composition among depth strata (proxy for iceberg disturbance), allowing for differences among transects (proxy for productivity). Non-metric multidimensional-scaling ordination (MDS) plots were produced to visualise the (dis)similarity of invertebrate assemblages (Clarke, 1993).

A two-way crossed SIMPER analysis (similarity percent analysis, Clarke, 1993) was employed to calculate the assemblage dissimilarities among the a priori sample groupings and to identify those species contributing most to the average dissimilarity between such groups (discriminatory species; only for groups being significantly different). Relatively high ratios $(>1.3)$ of the average dissimilarity to standard deviation of the dissimilarity were used to identify discriminatory species. To assess the possible effect of perturbation or stress on the invertebrate assemblages, the PRIMER routine MVDISP was run to calculate the relative dispersion of replicate samples within the depth strata sampling group (Warwick \& Clarke, 1993). The underlying assumptions here are that perturbation leads to increased variability in assemblage composition (i.e. reflected in greater variability between samples from the same sample group), and that disturbance of the seabed by icebergs represents such a perturbation. Relationships between the patterns of invertebrate assemblage composition and measured environmental variables (that included variables associated with the main hypotheses) were examined using the statistical correlation technique BVSTEP (e.g. Clarke \& Ainsworth, 1993). All pairwise combinations of environmental variables were visually examined (using draftsman plots) to assess the possible need for transformation and for cocorrelation prior to conducting the BVSTEP analysis. For pairs of variables with a correlation factor $\geq 0.9$, one variable was excluded from the analysis. Variables excluded from analyses and variables requiring log-transformations are listed in the results section (Table 5). All variables were normalised prior to the BVSTEP analysis.

\section{Results}

During the BioRoss Survey 53 grab, 55 sled and 29 trawl samples were taken on the shelf of the northwestern Ross Sea. These samples rendered 821 putative macro-invertebrate species, for 404 of which there are no abundance data available because their body form often fragments when sampled. Of these types of organism, the most speciose phyla were the Bryozoa (191 species, 24\% of all species) and Porifera (114 species, 14\% of all species). Other taxa contributed 11,675 individuals belonging to 417 species, of which the Mollusca was the most speciose phylum with 113 species, i.e. 14\% of all species. Annelida (Polychaeta and Hirudinea; 92 species) and Arthropoda (89 species) each contributed $11 \%$ of all species.

For all stations, biological and environmental data generated directly by the survey were added to the "BioRoss database" maintained by NIWA. Invertebrate data were also incorporated into the South Western Pacific Regional Ocean Biogeographic Information System (OBIS) portal (http://www.nzbois. niwa.co.nz) and summarised in the main OBIS node (http://www.iobis.org/). As part of the requirements for the publication of the results of the present study in this Special Issue, all data have also been submitted to ANTABIF (http://ww.biodiversity.aq/).

\section{Environment}

The basic results of the environmental data analysis have already been reported in Kröger \& Rowden (2008), but are repeated here for completeness. Surface chlorophyll $a$ data (averaged for the austral summer) were used as a proxy for primary productivity. There was neither an increasing gradient in surface water chlorophyll $a$ nor in sediment chlorophyll $a$ with increasing latitude. Differences in the surface chl $a$ values among the transect were nevertheless significant (ANOVA: $F=6.976$, $\mathrm{MS}=3803.5, d F=4, P \leq 0.001)$. Mean surface chlorophyll $a$ values ranged between 0.29 and $0.58 \mathrm{mg} \mathrm{m}^{-3}$; although the highest values were found for transect 5, the southernmost transect near Cape Hallett, the lowest values were found in transect 3, near Cape McCormick (Fig. 2a) with the difference being significant. The sediment chlorophyll $a$ values followed a similar pattern with highest values in transect $5\left(0.80 \mu \mathrm{g} \mathrm{g}^{-1}\right)$ and the lowest values occurring in transects 3 and $4\left(0.20 \mu \mathrm{g} \mathrm{g}^{-1}\right)$ (Fig. 2b). Overall, the sediment chlorophyll $a$ values were significantly different among the transects (ANOVA: $F=6.1345, \mathrm{MS}=960.99, d F=4, P \leq 0.001)$ with transect 5 being significantly different from transects 2 and 3 . 

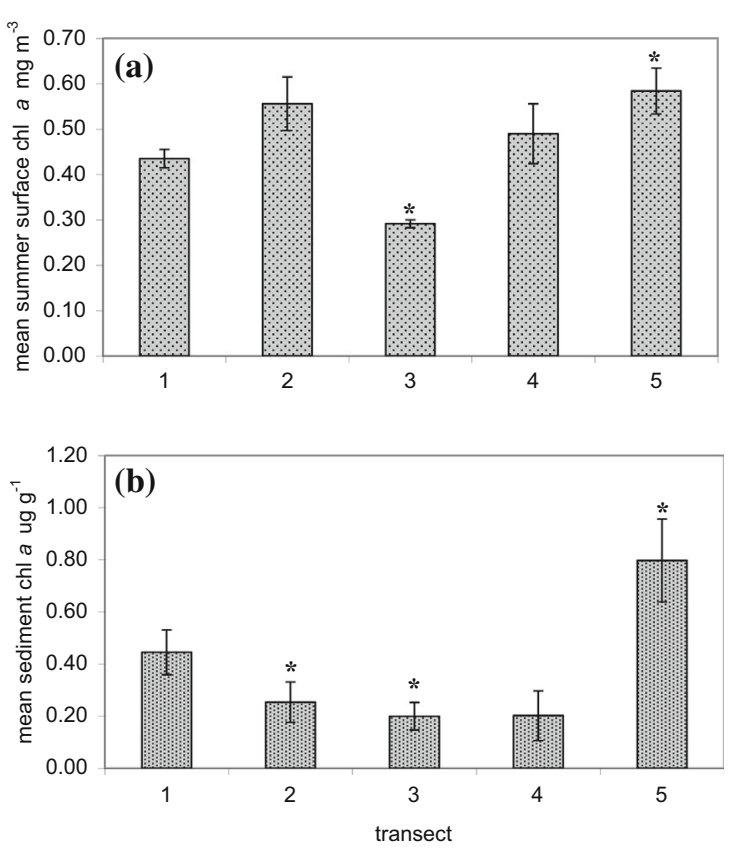

Fig. 2 a Mean surface water chl $a$ concentration $\left(\mathrm{mg} \mathrm{m}^{-3}\right)$ for austral summer (December-February 2004-2005; SeaWiFS), and $\mathbf{b}$ mean sediment chl $a$ content $\left(\mu \mathrm{g} \mathrm{g}^{-1}\right)$ for five transects in the northwestern Ross Sea shelf. Error bars indicate \pm 1 SE, stars indicate significant differences between transects

Iceberg scouring was most prevalent in the middepth stratum $(250-500 \mathrm{~m})$ with ca. $6 \%$ of the surveyed area covered by scour depressions. The extent of scouring was similar in the deep stratum (500-750 m), where ca. 5\% iceberg scour by area was detected. In the shallow depth stratum (50-250 m), $<1 \%$ of the bottom showed evidence of scour marks detectable by the analysis of multibeam data.

Mean values of all measured environmental variables (except those presented in Fig. 2) are detailed in Table 2. The maximum (mean) current speed decreased with latitude from $20.2 \mathrm{~cm} \mathrm{~s}^{-1}$ in transect 1 to $7.8 \mathrm{~m} \mathrm{~s}^{-1}$ in transect 5 . No difference was detected between the shallow and mid-strata (ca. $17.6 \mathrm{~cm} \mathrm{~s}^{-1}$ ), whereas in the deep stratum the maximum current speed was noticeably lower $\left(10.1 \mathrm{~cm} \mathrm{~s}^{-1}\right)$. Differences in mean annual ice cover amongst transects (59.3-62.4\%) as well as amongst depth strata (59.0-62.6\%) were minimal. The mean summer ice cover was slightly more varied, ranging between transects from $27.7 \%$ cover at transect 1 to $21.9 \%$ at transect 2 , and was highest in the shallow stratum (32.4\%) and lowest in the deep stratum (16.5\%). In all transects and strata, the sediment consisted mainly of poorly sorted very fine gravel and very coarse sand. Only in the deep stratum was the particle size slightly smaller and the sediment consisted of poorly sorted coarse to very coarse sand.

Test for differences among benthic assemblages for transects and depth strata

A visual inspection of the MDS plots for each assemblage type indicates some clustering of samples by transect, which is most obvious for the megaepifauna (Fig. 3). The ANOSIM tests revealed that the three macro-invertebrate assemblage types all showed significant differences among transects (Table 3). For both the macro-infauna and the macro-epifauna, differences in assemblage composition among the sample grouping transect were relatively weak (Global $R=0.25$ and $P \leq 0.001$ for both). Only for the mega-epifauna were the differences in composition pronounced (Global $R=0.49, P \leq 0.001$ ) among transects. Post hoc pairwise comparisons revealed that for all assemblage types, transect 5 was significantly different from transects 2 and 3 in its assemblage composition. Other pairwise differences in composition were observed between transects but these were not consistent among assemblage types (Table 3).

With regard to depth-related differences in assemblage composition, a visual inspection of the MDS plots for each assemblage type indicates that some clustering of samples is apparent, although patterns for the different depth strata differ among the assemblage types (Fig. 4). ANOSIM tests revealed that there were significant depth-related differences in assemblage composition (Table 3). Differences for the macroinfaunal assemblages amongst depth strata were nearly as weak as amongst transects (Global $R=0.26, \quad P \leq 0.001)$. For the macro-epifauna, depth-related differences in assemblage composition were stronger (Global $R=0.41, P \leq 0.001$ ) than differences among transects. For the mega-epifauna, depth-related differences were slightly less pronounced (Global $R=0.46, P \leq 0.001$ ) than differences among transects. Pairwise analysis revealed that for all three assemblage types differences between shallow and deep strata were significant (Table 3). Such differences were similar for the macro-infauna and the macro-epifauna $(R=0.51$ and 0.56 , respectively, with $P \leq 0.001$ for both), but were more 
Table 2 Mean values for environmental variables for 5 transects and 3 depth strata in the northwestern Ross Sea

\begin{tabular}{|c|c|c|c|c|c|c|c|c|}
\hline Environmental variable & 1 & 2 & 3 & 4 & 5 & $50-250 \mathrm{~m}$ & $250-500 \mathrm{~m}$ & $500-750 \mathrm{~m}$ \\
\hline Max. current speed $\left(\mathrm{m} \mathrm{s}^{-1}\right)$ & 20.17 & 16.81 & 20.62 & 12.46 & 7.76 & 17.56 & 17.77 & 10.07 \\
\hline Mean current direction $\left({ }^{\circ}\right)$ & 338.37 & 346.95 & 342.40 & 273.99 & 196.35 & 229.45 & 300.67 & 344.86 \\
\hline Annual ice cover (\%) & 61.65 & 59.30 & 59.46 & 61.80 & 62.40 & 62.64 & 61.53 & 59.00 \\
\hline Summer ice cover (\%) & 27.66 & 21.87 & 24.04 & 25.56 & 26.57 & 32.44 & 27.34 & 16.53 \\
\hline Particle size (phi) & -0.02 & -0.11 & 0.17 & -1.00 & -0.15 & -0.78 & -0.15 & 0.58 \\
\hline Sorting coefficient & 1.61 & 1.36 & 1.83 & 1.21 & 2.06 & 1.39 & 1.71 & 1.95 \\
\hline POC content $(\%)$ & 0.12 & 0.03 & 0.13 & 0.04 & 0.27 & 0.19 & 0.11 & 0.10 \\
\hline$\%$ Fine & 1.15 & 0.87 & 7.60 & 0.17 & 11.89 & 1.28 & 5.14 & 8.96 \\
\hline$\%$ Pebbles & 26.50 & 23.29 & 25.41 & 45.00 & 33.84 & 20.35 & 26.92 & 40.84 \\
\hline
\end{tabular}

Values for \pm 1 SE have been omitted for clarity in the table

pronounced for the mega-epifauna $(R=0.77$ with $P \leq 0.001)$. The macro-epifaunal and mega-epifaunal assemblages also showed significant differences in composition between the $250-500 \mathrm{~m}$ and the 500-750 m strata (macro-epifauna: $R=0.36$ with $P \leq 0.001$; mega-epifauna: $R=0.35$ with $P=0.024$ ).

Dissimilarities in assemblage composition

among transects and depth strata

Pairwise average dissimilarities for the assemblage types by transect and depth stratum are given in Table 4 with dissimilarities between transects ranging between $77.6 \%$ (macro-infauna: transects 3 and 2) and $93.1 \%$ (mega-epifauna: transects 5 and 2). Note that only significantly different pairwise comparisons are listed (2-way crossed ANOSIM; see Table 3).

Species contributing most to the average dissimilarities for pairwise comparisons of assemblages from transects are detailed in Online Resource 1. The contributions of individual species are small for all assemblage types. The cumulative dissimilarities of the 5 species contributing most is between $5.5 \%$ (macro-infauna: transects 3 and 5) and 10.7\% (megaepifauna: transects 3 and 1). No species stood out as a particularly good discriminating species for the macro-infaunal assemblages. For the macro-epifaunal assemblages, several species occurred consistently enough to be good discriminatory species between transects. Only three mega-epifaunal species qualified as discriminating species.

Dissimilarities between pairwise comparisons of depth strata were similar and slightly higher than the dissimilarities between transects. Lowest dissimilarity occurred for the macro-epifaunal assemblages between the shallow and the mid-depth strata $(80.6 \%)$, and highest dissimilarities occurred, for both the macro-epifaunal and the mega-epifaunal assemblages, between the shallow and the deep strata $(90.1 \%$ for both). Individual contributions to dissimilarities between depth strata were small for all assemblage types (below 2\%). For the five species contributing most to the dissimilarities in assemblages among depth strata see data in Online Resource 2.

Assessment of relative dispersion among assemblages from different depth strata

The pattern of dispersion, or apparent disturbance, with regard to depth strata was consistent among the three assemblage types. All assemblage types showed the highest variability in assemblage composition in the deep stratum (macro-infauna and mega-epifauna $=1.2$, macro-epifauna $=1.3$ ) and the least variability in the shallow stratum (macro-infauna $=0.5$, macro-epifauna $=0.7$, mega-epifauna $=0.9$ ). Dispersion values for the mid-stratum were between 0.9 (mega-epifauna) and 1.1 (macro-infauna).

Linking invertebrate assemblage composition to environmental data

In order to assess the relationships between the patterns of invertebrate assemblage composition and measured environmental variables the statistical correlation technique BVSTEP was used. Note that sediment variables could only be used for the correlation of macro-infaunal assemblage patterns with 


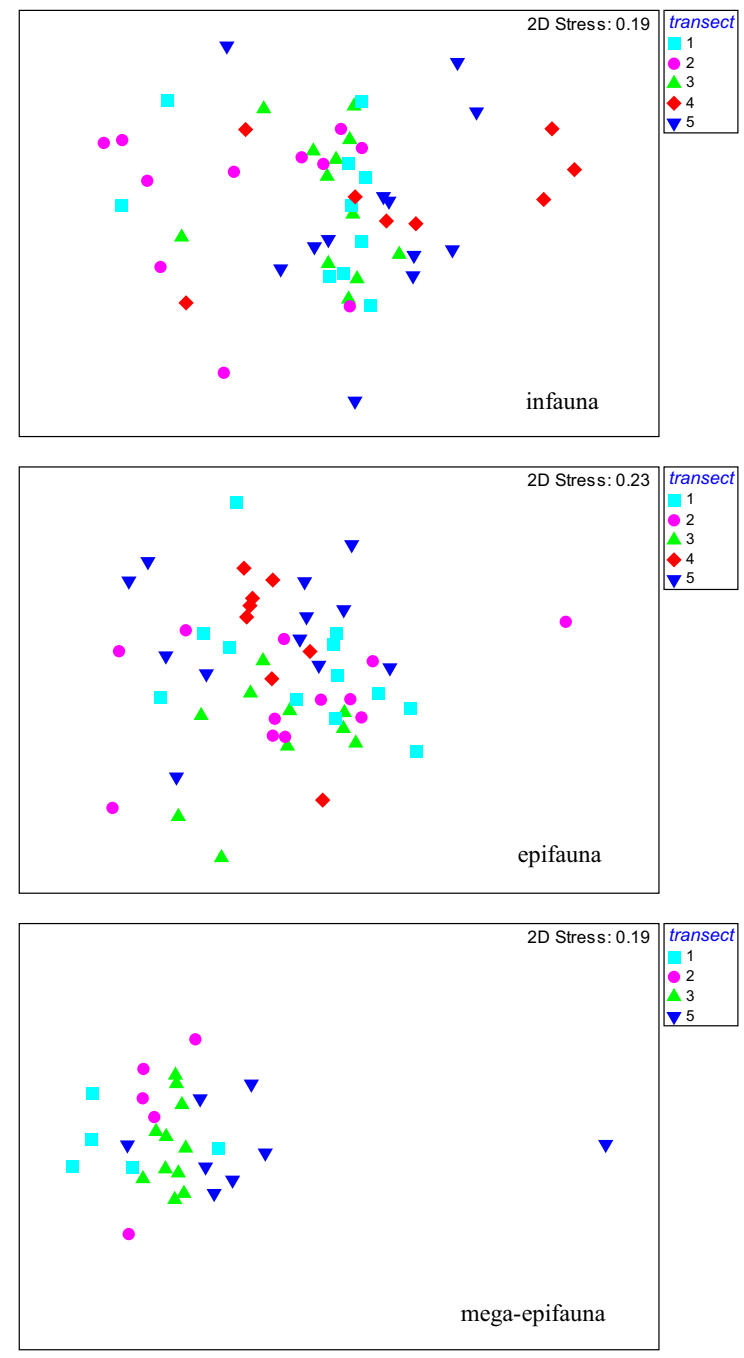

Fig. 3 MDS ordination of Bray-Curtis similarities for macroinfauna (top), macro-epifauna (middle), and mega-epifauna (bottom) abundance data (presence-absence transformed) for the northwestern Ross Sea shelf. Note for macro-epifauna plot outlier Station 6 (transect 3) is not shown, and for the megaepifauna there are no data for transect 4

environmental variables. Variables included in the analysis are listed in Table 5. Mean bottom current speed (correlated with maximum current speed) and median grain size (correlated with mean grain size) were excluded.

For the macro-infauna, the best Spearman rank correlation $(\rho=0.42, P=0.01)$ occurred for a combination of three environmental variables: mean ice cover in spring, mean ice cover in summer, and the sponge spicule content. For the macro-epifauna, a combination of water depth and the mean ice cover in summer best explained the observed assemblage patterns $(\rho=0.38, P=0.01)$, whereas for the mega-epifauna a combination of maximum current speed ( $\equiv$ mean current speed), mean surface chl $a$ in summer, mean ice cover in spring, and mean ice annual ice cover proved to have the best explanatory power $(\rho=0.39, P=0.01)$ (Table 6$)$.

\section{Discussion}

The environment of the northwestern Ross Sea shelf

The environmental differences between transects and depth strata did not conform to the initial prediction on which the sampling strategy was based. That is, differences among transect groups with respect to chlorophyll $a$ (both in the surface waters and the sediment) did not exhibit the linearity expected; and for depth strata, iceberg scour intensity was almost as great in the deepest stratum as the initially predicted middle depth stratum. It is perhaps not surprising that gradients in the proxy measures of primary productivity were not observed, considering the relatively short distance over which the transects were distributed. Mean surface water and sediment chlorophyll $a$ values are highest for transect 5, the southernmost transect off Cape Hallett, and the lowest for transect 3, off Cape McCormick. However, the pattern among transects was not entirely concordant for the two measures, with relatively high values for surface chlorophyll $a$ for transects 2 and 4 matched by relatively low values for these transects for sediment chl $a$. A mismatch between the two variables can be expected where the deposition of surface-derived matter to the seafloor is laterally advected by currents (Smith et al., 2006).

Iceberg scouring was least in the shallow depth stratum and most prevalent in the middle depth stratum, with ca. $6 \%$ of the surveyed area covered by scour depressions. However, the extent of scouring in the deep stratum (ca. 5\% iceberg scour by area) was similar to that of the middle stratum, and was observed to occur at depths of up to $550 \mathrm{~m}$. Gutt (2000) estimated that approximately $5 \%$ of the Antarctic shelf is affected by iceberg scouring. Iceberg scouring has been observed in the Weddell 
Table 3 Two-way crossed ANOSIM results for global and pairwise tests for significant differences among transects and depth strata for 3 benthic invertebrate assemblage types from the northwestern Ross Sea shelf

Bold $P$ values indicate significance at a level of $P \leq 0.05$. Abundance data presence-absence transformed

\begin{tabular}{|c|c|c|c|c|}
\hline Assemblage type & Sampling grouping & Groups compared & $R$ value & Significance level $P$ \\
\hline \multirow[t]{15}{*}{ Macro-infauna } & \multirow[t]{11}{*}{ Transect } & All transects & 0.248 & 0.001 \\
\hline & & 1,2 & 0.096 & 0.201 \\
\hline & & 1,4 & 0.003 & 0.498 \\
\hline & & 3,1 & 0.132 & 0.099 \\
\hline & & 3,2 & 0.301 & 0.03 \\
\hline & & 3,4 & 0.46 & 0.005 \\
\hline & & 3,5 & 0.382 & 0.006 \\
\hline & & 4,2 & 0.412 & 0.19 \\
\hline & & 5,1 & 0.143 & 0.099 \\
\hline & & 5,2 & 0.526 & 0.002 \\
\hline & & 5,4 & -0.147 & 0.826 \\
\hline & \multirow[t]{4}{*}{ Depth stratum } & All depth strata & 0.257 & 0.001 \\
\hline & & $250-500,50-250$ & 0.14 & 0.097 \\
\hline & & $500-750,50-250$ & 0.514 & 0.001 \\
\hline & & $500-750,250-500$ & 0.139 & 0.073 \\
\hline \multirow[t]{15}{*}{ Macro-epifauna } & \multirow[t]{11}{*}{ Transect } & All transects & 0.246 & 0.001 \\
\hline & & 1,2 & 0.193 & 0.05 \\
\hline & & 1,4 & 0.326 & 0.03 \\
\hline & & 3,1 & 0.199 & 0.024 \\
\hline & & 3,2 & 0.063 & 0.247 \\
\hline & & 3,4 & 0.313 & 0.023 \\
\hline & & 3,5 & 0.408 & 0.002 \\
\hline & & 4,2 & 0.35 & 0.021 \\
\hline & & 5,1 & 0.42 & 0.001 \\
\hline & & 5,2 & 0.203 & 0.018 \\
\hline & & 5,4 & 0.242 & 0.032 \\
\hline & \multirow[t]{4}{*}{ Depth stratum } & All depth strata & 0.406 & 0.001 \\
\hline & & $250-500,50-250$ & 0.366 & 0.001 \\
\hline & & $500-750,50-250$ & 0.563 & 0.001 \\
\hline & & $500-750,250-500$ & 0.359 & 0.001 \\
\hline \multirow[t]{11}{*}{ Mega-epifauna } & \multirow[t]{7}{*}{ Transect } & All transects & 0.492 & 0.001 \\
\hline & & 1,2 & 0.429 & 0.05 \\
\hline & & 3,1 & 0.667 & 0.017 \\
\hline & & 3,2 & 0.644 & 0.004 \\
\hline & & 3,5 & 0.465 & 0.004 \\
\hline & & 5,1 & 0.186 & 0.30 \\
\hline & & 5,2 & 0.483 & 0.044 \\
\hline & \multirow[t]{4}{*}{ Depth stratum } & All depth strata & 0.457 & 0.001 \\
\hline & & $250-500,50-250$ & 0.259 & 0.077 \\
\hline & & $500-750,50-250$ & 0.767 & 0.003 \\
\hline & & $500-750,250-500$ & 0.345 & 0.024 \\
\hline
\end{tabular}




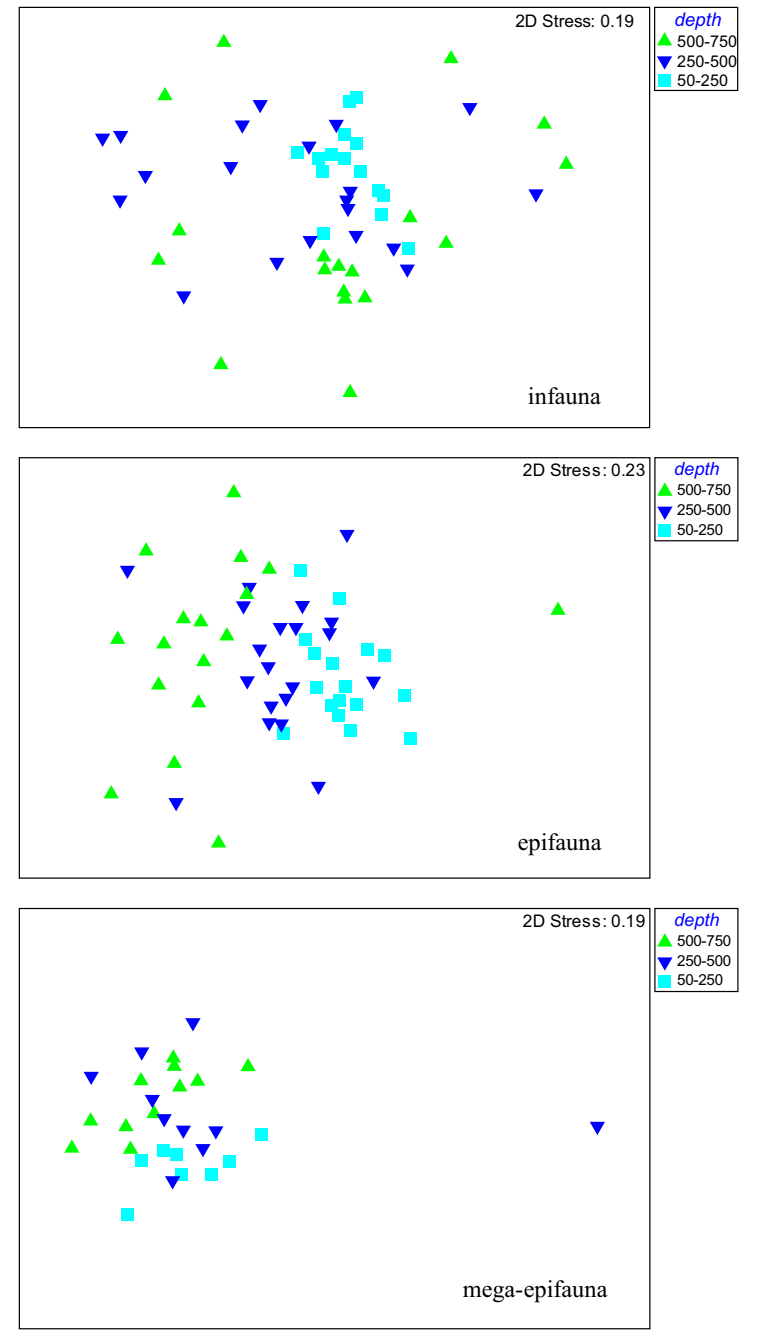

Fig. 4 MDS ordination of Bray-Curtis similarities for macroinfauna (top), macro-epifauna (middle), and mega-epifauna (bottom) abundance data (presence-absence transformed) for the northwestern Ross Sea shelf. Note for macro-epifauna plot the outlier Station 6 (depth stratum $500-750 \mathrm{~m}$ ) is not shown

Sea to reach depths of $500 \mathrm{~m}$ where such disturbance is predicted to be responsible for re-working seabed sediments over $54 \%$ of the shelf up to this depth over geological time (Barnes \& Lien, 1988). No predictions of patterns were made for the remaining environmental variables measured during the study. Some varied little over the area (e.g. sediment type), whilst others displayed a particular pattern (e.g. current speed). Below the results are discussed with respect to the three diversity hypotheses detailed in the Introduction.
Patterns for invertebrate assemblages on the northwestern Ross Sea shelf with respect to the energy-diversity hypothesis

Multivariate analyses revealed that macro-infauna, macro-epifauna, and mega-epifauna assemblages all showed significant differences in composition among transects. However, these differences were only pronounced for the mega-epifaunal component, possibly because such mobile and more sparsely distributed organisms may be controlled more closely by environmental variables that operate on large spatial scales (such as productivity) rather than those that vary on smaller scales, for instance, those that describe habitat heterogeneity (Barry et al., 2003). Pairwise comparisons revealed that for all assemblage types transect 5 was significantly different from transects 3 and 2 in its assemblage composition, and this result provides some support for the energy-diversity hypotheses tested. That is, assemblages from the area of the seabed beneath the most productive waters and receiving a relatively high amount of this overlying productivity (transect 5) were most different from those beneath the least productive waters (transect 3 ) or the seabed receiving the least of the overlying surface productivity (transects 2 and 3 ).

The relative frequency of occurrence of the bryozoan Tracheloptyx antarctica contributed the most to the measure of dissimilarity between the macroinfaunal assemblages of transects 5 and 3, and the polychaete Scoloplos marginatus mcleani between transects 5 and 2 . The bryozoan species was only marginally more frequent on transect 5 than transect 3 . This species is not strictly macro-infaunal, rather it is a macro-epifauna species sampled by the grab-presumably on small rock pebbles. Hence, the presence of this discriminating species probably reflects substrate availability more than a response to an environment with a potentially better food supply for these suspension feeding organisms.

The dominance of Scoloplos marginatus mcleani in the assemblage of transect 5, and its discriminatory role between transect 5 and 2 (where it occurred much less frequently and sediment chlorophyll $a$ content was low), could be a response to a greater food resource for deposit-feeding fauna along the southernmost transect as indicated by the higher chlorophyll $a$ content. Hilbig et al. (2006) concluded from a study 
Table 4 Average dissimilarity (\%) for groupwise comparisons of benthic invertebrate assemblages from the northwestern Ross Sea for the sampling groups transect and depth stratum analysed for each of 3 assemblage types

\begin{tabular}{|c|c|c|}
\hline Assemblage type & Sampling group & Average dissimilarity $\%$ \\
\hline \multicolumn{3}{|l|}{ Transect } \\
\hline \multirow[t]{4}{*}{ Macro-infauna } & 3,2 & 77.55 \\
\hline & 3,4 & 84.89 \\
\hline & 3,5 & 80.65 \\
\hline & 5,2 & 87.37 \\
\hline \multirow[t]{8}{*}{ Macro-epifauna } & 1,4 & 79.92 \\
\hline & 3,1 & 81.68 \\
\hline & 3,4 & 85.64 \\
\hline & 3,5 & 87.52 \\
\hline & 4,2 & 83.46 \\
\hline & 5,1 & 84.51 \\
\hline & 5,2 & 82.28 \\
\hline & 5,4 & 83.32 \\
\hline \multirow[t]{4}{*}{ Mega-epifauna } & 3,1 & 87.05 \\
\hline & 3,2 & 84.03 \\
\hline & 3,5 & 85.00 \\
\hline & 5,2 & 93.12 \\
\hline \multicolumn{3}{|l|}{ Depth stratum } \\
\hline Macro-infauna & $500-750,50-250$ & 84.56 \\
\hline \multirow[t]{3}{*}{ Macro-epifauna } & $500-750,250-500$ & 87.57 \\
\hline & $500-750,50-250$ & 90.13 \\
\hline & $250-500,50-250$ & 80.58 \\
\hline \multirow[t]{2}{*}{ Mega-epifauna } & $500-750,250-500$ & 87.57 \\
\hline & $500-750,50-250$ & 90.13 \\
\hline
\end{tabular}

Data presence-absence transformed. Only significantly different pairwise comparisons are listed (2-way crossed ANOSIM) be more frequent occurrence of potential prey items in the assemblages at the more productive transect.

The pycnogonids Ammothea carolinensis and Colossendeis notalis were the two species that came closest to being discriminatory species between the mega-epifauna assemblages of transect 5 and transects 3 and 2, respectively. These species were only found at transect 5. Little is known about the ecology of Antarctic pycnogonids (Jarre-Teichmann et al., 1997) but both species are considered to be predators of anemones, hydroids, and small polychaetes (Arango \& Brodie, 2003) and therefore could be benefiting from the increased availability of their potential prey items among the epifauna assemblage at transect 5.

The study of shallow macro-infauna assemblages by Cummings et al. (2010), which spanned a greater latitudinal range of the Ross Sea than the present study, also found that latitude was not a good proxy for primary productivity. However, their study found that the ratio of chlorophyll $a$ to phaeophytin in the 
Table 5 List of environmental variables included in BVSTEP analysis

\begin{tabular}{l}
\hline Environmental variables included in BVSTEP \\
\hline Water depth $(\mathrm{m})$ \\
Max bottom current speed $\left(\mathrm{cm}^{3} / \mathrm{s}\right)$ \\
Mean surface chl $a$ content spring $\left(\mathrm{mg} / \mathrm{m}^{3}\right)$ \\
Mean surface chl $a$ content summer $\left(\mathrm{mg} / \mathrm{m}^{3}\right)$ \\
Mean annual ice cover $(\%)$ \\
Mean spring ice cover $(\%)$ \\
Mean summer ice cover $(\%)$ \\
No of scours/\% area scoured \\
Distance to nearest ice scour $(\mathrm{km})$ \\
Biological habitat complexity (BHC) \\
Sorting coefficient ${ }^{\mathrm{a}}$ \\
Mean grain size (phi) \\
Sediment chl $a$ content $(\mathrm{ng} / \mathrm{g})^{\mathrm{a}}$ \\
$\%$ Particulate organic carbon $(\mathrm{POC})^{\mathrm{a}}$ \\
$\%$ Fines
\end{tabular}

${ }^{a}$ Variables only available for grab samples, i.e. only for correlation between macro-infaunal assemblages and environmental variables

sediment (as a measure of food availability) was one of the important variables that explained their patterns of assemblage composition. However, all of the most important environmental variables identified in their analysis only explained $\sim 17 \%$ of the variation in assemblage composition among locations. Studies by Rehm et al. (2006, 2011), which encompassed the same Latitudinal Gradient Project locations as sampled by Cummings et al. (2010), found that macroepifauna assemblages sampled by sled and agassiz trawl showed an overall difference in composition with location. These studies inferred from the scientific literature and the relative abundance of taxa characterising the three distinct assemblages they observed, that productivity and the supply of diatoms to the benthos was responsible for some of the patterns on the Ross sea shelf (Rehm et al., 2011).

There is some support from the ANOSIM and SIMPER results for the contention that large-scale differences in productivity influence the composition of macro-invertebrate assemblages on the northwestern shelf of the Ross Sea. The results of the BVSTEP correlation analysis provide further support for the energy-diversity hypothesis. This analysis indicated that for macro-infauna composition a combination of three environmental variables, the mean ice cover in spring and in summer, and the sponge spicule content, are particularly important. For the epifauna, a combination of water depth and the mean ice cover in summer best explained the observed assemblage patterns. For the mega-epifauna, a combination of maximum current speed ( $\equiv$ mean current speed), mean surface chlorophyll $a$ in summer, mean ice cover in spring, and mean annual ice cover were important. For all three assemblage types, variables associated with productivity were consistently implicated in the correlation analysis. Ice cover was the measured environmental variable that best correlated with the overall pattern of assemblage composition.

Table 6 Environmental variables (best combination and best single variable) explaining benthic invertebrate assemblage composition patterns for macro-infaunal, macro-epifaunal, and mega-epifaunal assemblages in the northwestern Ross Sea

\begin{tabular}{|c|c|c|c|c|}
\hline Assemblage type & Best combination & $\begin{array}{l}\text { Spearman rank } \\
\text { correlation } \rho\end{array}$ & Best single variable & $\begin{array}{l}\text { Spearman rank } \\
\text { correlation } \rho\end{array}$ \\
\hline Macro-infauna & $\begin{array}{l}\text { Mean ice cover summer, } \\
\text { mean ice cover spring, } \\
\text { sponge spicule content }\end{array}$ & $0.416 *$ & Mean ice cover spring & 0.323 \\
\hline Macro-epifauna & $\begin{array}{l}\text { Water depth, mean ice cover } \\
\text { summer }\end{array}$ & $0.381 *$ & Water depth & 0.359 \\
\hline Mega-epifauna & $\begin{array}{l}\text { Maximum current speed, } \\
\text { surface chl a summer, mean } \\
\text { ice cover spring, } \\
\text { mean annual ice cover }\end{array}$ & $0.389^{*}$ & Mean annual ice cover & 0.330 \\
\hline
\end{tabular}

* Significance level $P=0.01$ 
This result suggests that ice conditions, which can affect the amount of surface water primary productivity, and hence the subsequent availability of organic matter to the benthos (Cattaneo-Vietti et al., 1999; Lohrer et al., 2013), have a primary influence on the large-scale assemblage pattern for benthic invertebrates on the northwestern Ross Sea shelf. Other studies in the Antarctic have suggested links between spatial differences in the composition of benthic assemblages and ice cover, the related productivity of the overlying water, and the transfer of organic matter derived from productivity to the seabed (e.g. see review of Gutt, 2000). In the Ross Sea, Cummings et al. (2006) suggested ice cover (using latitude as a proxy) was the most important factor controlling community composition in shallow waters $(<25 \mathrm{~m})$. In contrast, a study by Barry et al. (2003) in deeper water (270-1,137 m) in the southwestern Ross Sea found that the distribution of benthic assemblages was "largely unrelated to the distribution of sea ice" and there was only a "relatively weak link with upper ocean productivity".

Although water depth is identified by the BVSTEP analysis as a contributory variable for the macroepifauna assemblage pattern, it is worth remembering that depth per se does not directly influence benthic organisms, but variables which co-correlate with this factor are likely to structure the composition of assemblages. For example, changes with depth will influence the amount and quality of organic material that arrives at the sea bed (Fabiano et al., 1997). Thus, depth may act as a proxy for the amount of initial food (energy) that is supplied and utilised by the macroepifaunal assemblage.

Patterns for invertebrate assemblages

on the northwestern Ross Sea shelf with respect to the disturbance-diversity hypothesis

The multivariate analysis revealed that overall there were significant differences in assemblage composition among the depth strata sampled. For the infaunal assemblages, the differences were nearly as weak as among transects, whilst for the macro-epifauna depthrelated differences were stronger than among transects. For the mega-epifauna, depth-related differences were slightly less than transect differences. Pairwise analysis revealed that for all three assemblage types differences between the shallow (least disturbed by icebergs) and the deep (iceberg disturbed) strata were relatively large and significant. However, only the macro-epifaunal assemblages also show significant differences in composition between the middle stratum (the most disturbed by icebergs) and the shallow stratum. Thus, only for this assemblage type is there support for the disturbancediversity hypothesis.

It is perhaps understandable that the macro-epifauna, relative to the other two assemblage components, would provide support for the disturbance hypothesis. The macro-infaunal assemblage, though susceptible to disturbance, as a whole would likely recover relatively rapidly post-disturbance because not all components of the infauna would have been directly affected by scour disturbance, and colonisation would include immediate local migration of motile species. The mega-epifauna assemblage includes organisms that would be able to physically avoid the iceberg, and because these organisms generally have a wider distribution, the impact upon this assemblage would be less obvious. However, the macro-epifauna, which contains a large proportion of sessile organisms, is more likely to be directly affected by the passage of icebergs, and the assemblage will take some time to recover completely from such a disturbance. Estimates of recovery from iceberg scour range from $\leq 50$ years (Conlan et al., 1998 for Arctic macrofauna) to 250-500 years (Gutt \& Starmans, 2001 for Antarctic shelf mega-fauna). Thus overall, the patterns of macro-epifauna assemblage composition on the northwestern Ross Sea shelf are likely to be more closely controlled by iceberg disturbance than those of the other two assemblage types. Thrush et al. (2010) observed a stronger effect on shallow water macrothan mega-fauna to iceberg disturbance regimes, although attributed the difference between the assemblages to the effects of iceberg 'breakout' on regional primary production and food supply rather than disturbance per se.

Other analyses provide some additional support for the disturbance hypothesis. The similarity level (a measure of $\beta$-diversity whereby low similarity equals high species turnover or high $\beta$-diversity) of the assemblages from the two deepest strata were lower $(14.7-23.7 \%)$ than that of the assemblages from the shallowest stratum (25.2-37.4\%). Low similarity is expected among samples from areas where assemblages are patchily disturbed (Warwick \& Clarke, 
1993), as is the case for those depth strata where iceberg scours with paths tens of metres wide and several $\mathrm{km}$ long are distributed over 5-6\% of the strata area. This result is reflected in the measure of relative dispersion which was also used to assess the possible effect of the iceberg disturbance. The pattern of dispersion with depth was consistent among the three assemblage types. The highest variability in assemblage composition is seen in the two deeper strata and the least variability in the shallow stratum. However, the deepest stratum had the highest values for dispersion. The reason for this latter observation could be independent of disturbance, as high levels of dispersion are relatively common among benthic samples where the patchy availability of food or habitat is thought to be responsible for low levels of similarity among assemblages.

The SIMPER analysis for the macro-epifauna assemblage revealed that individual species contributions to dissimilarities between depth strata were small. However, the relative occurrence of some species did identify them as good discriminating species between the composition of the assemblages from the least (shallow) and most (middle and deep) disturbed strata. The sabellid polychaete Perkinsiana littoralis occurred frequently in the shallow (where it was identified as the only typifying species for this assemblage type), occasionally in the middle but not at all in the deep stratum and thus proved to be a particularly good discriminating species for the macro-epifauna assemblages. In addition, the motile polynoid polychaete Harmothoe fuligineum and the ophiuroid Ophiosteira echinulata were also identified (but less so) as discriminating species between the macro-epifaunal assemblages, being more frequent in the shallow than and deep stratum. It is reasonable to propose that slow-growing, sessile, filter-feeding organisms would, because of their life habit, occur more often in undisturbed than disturbed environments. Gerdes et al. (2003) compared the macro-invertebrate fauna of young and old iceberg scours and undisturbed areas in the Weddell Sea, and found that sessile, filter-feeding polychaete species did not occur at scour sites. Teixido et al. (2004) and Jones et al. (2007) found that sessile epifaunal species with sheet-like growth-forms such as sabellids are taxa characteristic of early recovery stages from iceberg scour in relatively shallow water (117-265; $245 \mathrm{~m}$, respectively). Thus, it is possible that the difference in the distribution of $P$. littoralis could at least in part be a result of the relative acrossshelf differences in iceberg disturbance. It is also reasonable to propose that in areas where icebergs have disturbed the seabed and sessile species are less abundant, the organisms that can associate with those species would also be less abundant. Thus, the pattern of relative occurrence of motile species, such as $H$. fuligineum, which is a scavenger, and O. echinulata, that would presumably benefit either directly (e.g. physical habitat, predation refuge) or indirectly (e.g. food entrapment) from the structure provided by sessile fauna, such as $P$. littoralis, could also be explained at least partly by the affect of disturbance on assemblage composition. However, alternative explanations for the more frequent occurrence of these three species in the shallow (but less disturbed) strata could be related to other factors that reflect their generally shallow water depth distribution (maximum recorded depths of 219, 525, and $630 \mathrm{~m}$ have been recorded for $P$. littoralis, $O$. echinulata, and H. fuligineum, respectively, in Antarctic waters-http://eol.org).

Patterns for invertebrate assemblages on the northwestern Ross Sea shelf with respect to the habitat heterogeneity-diversity hypothesis

The likely importance of sponge spicules in Antarctic sediments on shelf-wide scales has previously been noted (Bullivant, 1967b; Barthel \& Gutt, 1992), and a recent study that analysed seafloor imagery from the southeastern Weddell Sea has demonstrated that macro- and mega-epibenthic assemblages are influenced by the local presence of sponge spicule mats (Gutt et al., 2013a, b). The results of the present study indicate that the influence of relatively high densities of sponge spicules in the sediment on macro-infaunal assemblages can potentially operate at large scales in the northwestern Ross Sea. Assemblages from stations on transect 5 that were relatively similar to one another occurred where sponge spicule content of the sediment was generally high. However, sponge spicule density was high at some other stations that clustered with or towards the transect 5 stations, notably two stations from the deep stratum of transect 3 and one deep station from transect 1 . Thus, it is likely that local differences in sponge spicule content can also determine small spatial scale 
differences in macro-infaunal assemblage composition since the presence of sponge spicules in sediments provides for a wider range of niches for sessile and motile polychaetes (Knox \& Cameron, 1998) and presumably other infaunal taxa. It is possible that sponge spicules influence macro-infauna in other ways, through their presumably abrasive nature, or the spicules acting as a surface on which bacteria or microphytobenthic organisms (potential food for some infaunal species) can proliferate or become 'trapped'.

Differences in measures of the sediment sorting coefficient (an index of local habitat heterogeneity provided by the sediment itself) between stations across the study area were relatively small. This local scale variable was not identified by the correlation analysis as being of importance for the macro-infaunal assemblages, and thus, this result provides no support for the habitat heterogeneity hypothesis.

Biogenic habitat complexity also did not feature as an important environmental variable for the fauna sampled by the grab, contrary to expectation. However, this result is not entirely surprising given that the organisms sampled by the grab were mainly infaunal (see also Kröger \& Rowden, 2008). It is reasonable to expect that the composition of the macro-epifaunal and mega-epifaunal components of the invertebrate fauna (sampled by the epibenthic sled and trawl) would be more closely controlled by the biogenic habitat complexity; unfortunately, no suitable photographic image recovery was associated with sampling by sled or trawl that could have been used to derive complexity indices.

The structural heterogeneity of a habitat has previously been invoked as an important factor influencing the composition of associated communities. For example, a more complex habitat providing a wider range of niches and thus a higher number and wider array of species that can potentially occupy that habitat within a given area (MacArthur, 1972). In Antarctic waters, Siciński (2004) showed that for the coastal polychaete assemblages of King George Island (South Shetland Islands) the sorting coefficient is, amongst other sediment characteristics, an important structuring factor. A separate examination of the polychaete component of the infaunal assemblage sampled by the BioRoss Survey also indicated that this measure of habitat heterogeneity was a structuring agent (Kröger \& Rowden, 2008).
The role of interacting environmental drivers in determining invertebrate assemblage composition on the northwestern Ross Sea shelf

The intermediate scale measure of iceberg disturbance used in the present study, iceberg scour intensity within a $1 \mathrm{~km}$ radius of a station, was not correlated to the biological pattern for the invertebrate assemblages sampled (see also Kröger \& Rowden, 2008). The role of iceberg scouring at similar and smaller spatial scales has been demonstrated previously as being important in structuring benthic assemblages in polar regions (Gerdes et al., 2003; Conlan \& Kvitek, 2005; Jones et al., 2007; Smale et al., 2007, 2008). The failure of the present study to demonstrate any linkage between this scale of disturbance and the composition of invertebrate assemblages is likely a result of a sampling artefact. That is, the small number of replicates taken within each sampling strata was probably insufficient to encompass the level of variability imposed upon the benthic assemblages by iceberg disturbance (e.g. none of the random samples were taken within a scour). However, the results of ANOSIM/SIMPER revealed iceberg disturbance could be playing some part in the structuring of the macro-epifaunal assemblages at a larger scale. Some of the among-transect differences in assemblage composition could be the result of differences in iceberg-related disturbance along the shelf as well as across it. The direction of the prevailing currents along the Ross Sea shelf is thought to be responsible for transporting icebergs in a northerly direction (see Thrush et al., 2006 for explanation). As icebergs travel to the northernmost reaches of the study area, the shelf narrows, and the currents and the shelf topography together are likely to constrain the transport of icebergs through the area of deeper water. Hence, the influence of iceberg scour disturbance would not only be greater in the deeper strata than the shallow stratum, but the difference in the density of scours between coastal and deeper waters would increase in a northerly direction and be reflected in along-shelf differences in the benthic assemblages. Results from the present study indicate that for the most northerly (1) and the most southerly (5) transect the \% seabed scoured for the mid- and deep strata compared to the shallow strata is 38 and 5 times greater, respectively. This difference across the shelf could partly explain the compositional dissimilarity between the macro- 
epifauna assemblages of transect 1 and 5. An acrossshelf difference in assemblage composition was observed by Jones et al. (2007) for mega-epifauna (documented by seabed images), who concluded that depth-related differences in iceberg disturbance (in the opposite direction to that of the present study) were largely responsible for benthic distribution patterns adjacent to the Fimbul ice shelf in the Weddell Sea. The mechanisms by which grounded icebergs influence invertebrate assemblages could act directly through the removal of fauna (and creation of space) (Gutt \& Piepenburg, 2003), and/or indirectly through changes in sediment characteristics via the ploughing of the sediment, and modifications to the seafloor topography creating habitat heterogeneity (Gerdes et al., 2008). Thus, it seems possible that the largescale patterns in assemblage composition observed by the present study could in part result from this environmental driver, rather than from physical disturbance per se. Grounded icebergs and iceberg scours can also cause changes in levels of primary production (Arrigo \& van Dijken, 2004; Dayton et al., 2013), local current patterns, and therefore also in sedimentation patterns (e.g. Barnes \& Conlan, 2007). Thus, iceberg scouring could be responsible, secondarily, for the pattern of benthic assemblage composition that is controlled primarily by the relative availability of food derived from phytoplankton.

\section{Conclusion}

Overall, the results of the present study demonstrate that a number of, sometimes interacting, environmental drivers operating at different spatial scales are responsible for structuring benthic assemblages on the northwestern Ross Sea shelf. At the time the present study was initiated, the influence of multiple drivers working at varying scales had been inferred for Antarctic shelf communities (Gutt, 2000), and has subsequently been supported by studies similar to the one reported here albeit on somewhat different spatial scales (e.g. Barry et al., 2003; Cummings et al., 2006, 2010). It seems then that the paradigms that are beginning to solidify for the environmental control of coastal communities in the Ross Sea (Thrush et al., 2006; Thrush \& Cummings, 2011) may be partially extended into the offshore realms of the shelf. However, the results of the present study do not provide support for the extent of decoupling between pelagic and benthic systems suggested by the research of Barry et al. (2003) for the deeper waters of the southwestern Ross Sea. There are strong indications that large-scale oceanographic and local habitat variables are both responsible, without the latter being of particular importance, for the patterns of assemblage composition observed in the northwestern Ross Sea. It is possible that the findings of Barry et al. (2003) are either particular to the component of the fauna they examined (although the patterns for mega-epifauna revealed by the present study tend to contradict such a suggestion) or the region examined. Substrate characteristics vary considerably in the southwestern area, whereas in the northwestern area of the Ross Sea shelf the sediment type is relatively homogenous. It is probable that the relative strength of the benthopelagic coupling could change along the shelf. That is, because it is likely that the benthos of the deeper waters are partly dependent upon the lateral transport of organic material from coastal waters (Isla et al., 2006), with the decrease in shelf width northwards the relative linkage between pelagic processes and benthic assemblage composition could be stronger in the north than in the south of the shelf region studied. This contention remains to be tested for the northwestern Ross Sea shelf, although there is some evidence from other sites in Antarctica that such factors may influence the strength of bentho-pelagic coupling and ultimately assemblage composition (e.g. Smith et al., 2006).

Acknowledgments The BioRoss Survey was a large, complicated, and hugely ambitious project that relied upon the efforts and skills of many people, both within NIWA and at other institutes and agencies in New Zealand and elsewhere. Thus, it is only proper for the authors of this publication to provide a relatively extensive acknowledgement of their contribution to the project (see Online Resource 3). Special thanks must be extended to the captain of the RV Tangaroa, A. Leachman, and his crew, the voyage leader J. Mitchell, other members of the biodiversity science party (N. Bagley, I. Everson, L. Ghigliotti, A. Hill, G. La Mesa, A.-N. Lörz, P. McMillan, S. Schiaparelli, R. Stewart, J. Visser), and other scientific personnel of the BioRoss Survey (voyage TAN0402). The BioRoss Survey was funded by the then New Zealand Ministry of Fisheries (now Ministry for Primary Industries) under Project ZBD2003-03, and acknowledgment is also due to the various staff at the ministry who at one time or another supported the management of the Project (Jacqui Burgess, Ben Sharp, Mary Livingston) and to Don Robertson at NIWA who managed the project from inception to completion. 
Open Access This article is distributed under the terms of the Creative Commons Attribution 4.0 International License (http:// creativecommons.org/licenses/by/4.0/), which permits unrestricted use, distribution, and reproduction in any medium, provided you give appropriate credit to the original author(s) and the source, provide a link to the Creative Commons license, and indicate if changes were made.

\section{References}

Arango, C. \& G. Brodie, 2003. Observations of predation on the tropical nudibranch Okenia sp. by the sea spider Anoplodactylus longiceps Williams (Arthropoda: Pycnogonida). Veliger 46: 99-101.

Arntz, W. E., T. Brey \& V. A. Gallardo, 1994. Antarctic zoobenthos. Oceanography and Marine Biology: An Annual Review 32: 241-304.

Arrigo, K., D. Worthen, A. Schnell \& M. Lizotte, 1998. Primary production in Southern Ocean waters. Journal of Geophysical Research C 103: 15587-15600.

Arrigo, K. \& G. van Dijken, 2004. Annual changes in sea-ice, chlorophyll $a$, and primary production in the Ross Sea, Antarctica. Deep Sea Research II 51: 117-138.

Bale, A. J. \& A. J. Kenny, 2005. Sediment analysis and seabed characterisation. In Eleftheriou, A. \& A. McIntyre (eds), Methods for the Study of Marine Benthos, 3rd ed. Blackwell Publishing, Hoboken: 43-86.

Barnes, D. K. A. \& K. E. Conlan, 2007. Disturbance, colonization and development of Antarctic benthic communities. Philosophical Transactions of the Royal Society B: Biological Sciences 362: 11-38.

Barnes, P. W. \& R. Lien, 1988. Icebergs rework shelf sediments to $500 \mathrm{~m}$ off Antarctica. Geology 16: 1130.

Barnes, D. K. A. \& L. S. Peck, 2008. Vulnerability of Antarctic shelf biodiversity to predicted regional warming. Climate Research 37: 149-163.

Barry, J., J. Grebmeier, J. Smith \& R. Dunbar, 2003. Oceanographic versus seafloor-habitat control of benthic megafaunal communities in the S.W. Ross Sea, Antarctica. In DiTullio, G. \& R. Dunbar (eds), Biogeochemistry of the Ross Sea, Vol. 78. American Geophysical Union, Washington, DC: $327-353$.

Barry, J. P. \& P. K. Dayton, 1988. Current patterns in McMurdo Sound, Antarctica and their relationship to local biotic communities. Polar Biology 8(5): 367-376.

Barthel, D. \& J. Gutt, 1992. Sponge associations in the eastern Weddell Sea. Antarctic Science 4: 137-150.

Blazewicz-Paszkowycz, M. \& J. Sicinski, 2014. Diversity and distribution of Tanaidacea (Crustacea) along the Victoria Land Transect (Ross Sea, Southern Ocean). Polar Biology 37: 519-529.

Bradford-Grieve, J., G. Fenwick, 2002. A review of the current knowledge describing the biodiversity of the Balleny Islands. Final Research Report for Ministry of Fisheries Research Project ZBD2000/01 (unpublished report held in NIWA library, Wellington).
Bray, J. R. \& T. J. Curtis, 1957. An ordination of the upland forest communities of Southern Wisconsin. Ecological Monographs 27: 325-349.

Bullivant, J. S., 1967a. New Zealand Oceanographic Institute Ross Sea investigations, 1958-60: general account and station list. In Bullivant, J. S. \& J. H. Dearborn (eds), The Fauna of the Ross Sea, Part 5. General Accounts, Station Lists, and Benthic Ecology. New Zealand Department of Scientific and Industrial Research Bulletin Vol. 176, pp. 9-29.

Bullivant, J. S., 1967b. Ecology of the Ross Sea benthos. In Bullivant, J. S. \& J. H. Dearborn (eds) The Fauna of the Ross Sea, Part 5. General Accounts, Station Lists, and Benthic Ecology. New Zealand Department of Scientific and Industrial Research Bulletin Vol. 176, pp. 49-75.

Cattaneo-Vietti, R., M. Chiantore, C. Misic, P. Povero \& M. Fabiano, 1999. The role of pelagic-benthic coupling in structuring littoral benthic communities at Terra Nova Bay (Ross Sea) and in the Straits of Magellan. Scientia Marina 63(Suppl. 1): 113-121.

Cantone, G., A. Castelli \& M. C. Gambi, 2000. Benthic polychaetes of Terra Nova Bay and Ross Sea: species composition, biogeography, and ecological role. In Faranda, F. M., L. Guglielmo \& A. Ianora (eds), Ross Sea Ecology: Italiantartide Expeditions (1987-1995). Springer, New York: 551-561.

Choudhury, M. \& A. Brandt, 2007. Composition and distribution of benthic isopod (Crustacea, Malacostraca) families off the Victoria-Land Coast (Ross Sea, Antarctica). Polar Biology 30: 1431-1437.

Clarke, K. R., 1993. Non-parametric multivariate analyses of changes in community structure. Australian Journal of Ecology 18: 117-143.

Clarke, K. R. \& M. Ainsworth, 1993. A method of linking multivariate community structure to environmental variables. Marine Ecology Progress Series 92: 205-219.

Clarke, K. R. \& R. N. Gorley, 2006. PRIMER v6: User Manual/ Tutorial PRIMER-E. PRIMER-E, Plymouth.

Clarke, A. \& C. Harris, 2003. Polar marine ecosystems: major threats and future change. Environmental Conservation 30: $1-25$.

Conlan, K. E. \& R. G. Kvitek, 2005. Recolonization of softsediment ice scours on an exposed Arctic coast. Marine Ecology Progress Series 286: 21-42.

Conlan, K. E., H. S. Lenihan, R. G. Kvitek \& J. S. Oliver, 1998. Ice scour disturbance to benthic communities in the Canadian High Arctic. Marine Ecology Progress Series 166: $1-16$.

Cummings, V. J., S. Thrush, A. Norkko, N. Andrew, J. Hewitt, G. Funnell \& A.-M. Schwarz, 2006. Accounting for local scale variability in benthos: implications for future assessments of latitudinal trends in the coastal Ross Sea. Antarctic Science 18: 633-644.

Cummings, V. J., S. F. Thrush, M. Chiantore, J. E. Hewitt \& R. Cattaneo-Vietti, 2010. Macrobenthic communities of the north-western Ross Sea shelf: links to depth, sediment characteristics and latitude. Antarctic Science 22(6): 793-804.

Currie, D. J., A. P. Francis \& J. T. Kerr, 1999. Some general propositions about the study of spatial patterns of species richness. Ecoscience 6(3): 392-399. 
Dayton, P. K., G. A. Robilliard \& R. T. Paine, 1970. Benthic faunal zonation as a result of anchor ice at McMurdo Sound, Antarctica. In Holdgate, M. W. (ed.), Antarctic Ecology. Academic Press: Scientific Committee on Antarctic Research, London and New York: 244-258.

Dayton, P. K., B. J. Mordida \& F. Bacon, 1994. Polar marine communities. American Zoologist 34: 90-99.

Dayton, P. K., S. Kim, S. C. Jarrell, J. S. Oliver, K. Hammerstrom, J. L. Fisher, K. O'Conner, J. S. Barber, G. Robilliard, J. Barry, A. R. Thurber \& K. Conlan, 2013. Recruitment, growth and mortality of an Antarctic hexactinellid sponge, Anoxycalyx joubini. PLos ONE 8: e56939.

De Domenico, F., M. Chiantore, S. Buongiovanni, M. P. Ferranti, S. Ghione, S. Thrush, V. Cummings, J. Hewitt, K. Kroeger \& R. Cattaneo-Vietti, 2006. Latitude versus local effects on echinoderm assemblages along the Victoria Land coast, Ross Sea, Antarctica. Antarctic Science 18: 655-662.

Environment Canada, 1994. Manual of analytical methods. Major ions and nutrients, vol 1. National Laboratory for Environmental Testing, Canadian Center for Inland Waters, Burlington, ON, Canada.

Fabiano, M., M. Chiantore, P. Povero, R. Cattaneo-Vietti, A. Pusceddu, C. Misic \& G. Albertelli, 1997. Short-term variation in particulate matter flux in Terra Nva Bay, Ross Sea. Antarctic Science 9: 143-149.

Fabiano, M. \& R. Danovaro, 1998. Enzymatic activity, bacterial distribution, and organic matter composition in sediments of the Ross Sea (Antarctica). Applied and Environmental Microbiology 64: 3838-3845.

Folk, R. L. \& W. C. Ward, 1957. Brazos River Bar: a study in the significance of grain size parameters. Journal of Sedimentary Petrology 27(1): 3-26.

Gallagher, M., W. J. Ambrose \& P. Renaud, 1998. Comparative studies in biochemical composition of benthic invertebrates (bivalves, ophiuroids) from the Northeast Water (NEW) Polynya. Polar Biology 19: 167-171.

Galéron, J., R. L. Herman, P. M. Arnaud, W. E. Arntz, S. Hain \& M. Klages, 1992. Macrofaunal communities on the continental shelf and slope of the southeastern Weddell Sea, Antarctica. Polar Biology 12: 283-290.

Gallardo, V. A., 1987. The sublittoral macrofaunal benthos of the Antarctic shelf. Environmental International 13: 71-81.

Gerdes, D., M. Klages, W. E. Arntz, R. L. Herman, J. Galéron \& S. Hain, 1992. Quantitative investigations on macrobenthos communities of the southeastern Weddell Sea shelf based on multibox corer samples. Polar Biology 12: 291-301.

Gerdes, D., B. Hilbig \& A. Montiel, 2003. Impact of iceberg scouring on macrobenthic communities in the highAntarctic Weddell Sea. Polar Biology 26: 295-301.

Gerdes, D., E. Isla, R. Knust, K. Mintenbeck \& S. Rossi, 2008. Response of Antarctic benthic communities to disturbance: first results from the artificial Benthic Disturbance Experiment on the eastern Weddell Sea Shelf, Antartica. Polar Biology 31: 1469-1480.

Ghinglione, C., M. C. Alvaro, H. J. Griffiths, K. Linse \& S. Schiaparelli, 2013. Ross Sea Mollusca from the latitudinal gradient program: R/V Italica 2004 Rauschert dredge samples. ZooKeys 341: 37-48.
Grebmeier, J. M. \& J. P. Barry, 1991. The influence of oceanographic processes on pelagic-benthic coupling in polar regions: a benthic perspective. Journal of Marine Systems 2: 498-518.

Gutt, J., 2000. Some "driving forces" structuring communities of the sublittoral Antarctic macrobenthos. Antarctic Science 12: 297-313.

Gutt, J., 2007. Antarctic macro-zoobenthic communities: a review and an ecological classification. Antarctic Science 19: 165-182.

Gutt, J. \& D. Piepenburg, 2003. Scale-dependent impacts of catastrophic disturbances by grounding icebergs on the diversity of Antarctic benthos. Marine Ecology Progress Series 253: 77-83.

Gutt, J. \& T. Schickan, 1998. Epibiotic relationships in Antarctic benthos. Antarctic Science 10: 398-405.

Gutt, J. \& A. Starmans, 1998. Structure and biodiversity of megabenthos in Weddell and Lazarev Seas (Antarctica): ecological role of physical parameters and biological interactions. Polar Biology 20: 229-247.

Gutt, J. \& A. Starmans, 2001. Quantification of iceberg impact and benthic recolonisation patterns in the Weddell Sea (Antarctica). Polar Biology 24: 615-619.

Gutt, J., A. Starmans \& G. Dieckmann, 1996. Impact of iceberg scouring on polar benthic habitats. Marine Ecology Progress Series 137: 311-316.

Gutt, J., A. Starmans \& G. Dieckmann, 1998. Phytodetritus deposited on the Antarctic shelf and upper slope: its relevance for the benthic system. Journal of Marine Systems 17: 435-444.

Gutt, J., A. Böhmer \& W. Dimmler, 2013a. Antarctic sponge spicule mats shape macrobenthic diversity and act as a silicon trap. Marine Ecology Progress Series 480: 57-71.

Gutt, J., H. J. Griffiths \& C. D. Jones, 2013b. Circum-polar overview and spatial heterogeneity of Antarctic macrobenthic communities. Marine Biodiversity 43: 481-487.

Hilbig, B., D. Gerdes \& A. Montiel, 2006. Distribution patterns and biodiversity in polychaete communities of the Weddell Sea and Antarctic Peninsula area (Southern Ocean). Journal of the Marine Biological Association of the United Kingdom 86: 711-725.

Howard-Williams, C., D. Peterson, W. B. Lyons, R. CattaneoVietti \& S. Gordon, 2006. Measuring ecosystem response in a rapidly changing environment: the Latitudinal Gradient Project. Antarctic Science 18: 465-471.

Humphreys G. F. \& S. W. Jeffrey, 1997. Tests of accuracy of spectrophotometric equations for the simultaneous determination of chlorophylls a, b, c1 and c2. In Jeffrey, S. W., R. F. C. Mantoura \& S. W. Wright (eds), Phytoplankton Pigments in Oceanography: Guidelines to Modern Methods. Monographs on Oceanographic Methodology 10. Unesco, pp. 616-621.

Iampietro, P. J., R. G. Kvitek \& E. Morris, 2005. Recent advances in automated genus-specific marine habitat mapping enabled by high-resolution multibeam bathymetry. Marine Technology Society Journal 39: 83-93.

Isla, E., S. Rossi, A. Palanques, J.-M. Gili, D. Gerdes \& W. Arntz, 2006. Biochemical composition of marine sediment from the eastern Weddell Sea (Antarctica): high nutritive value in a high benthic-biomass environment. Journal of Marine Systems 60: 255-267. 
Jarre-Teichmann, A., T. Brey, U. V. Bathmann, C. Dahm, G. S. Dieckmann, M. Gorny, M. Klages, F. Pagés, J. Plötz, S. B. Schnack-Schiel, M. Stiller \& W. E. Arntz, 1997. Trophic flows in the benthic shelf communities of the eastern Weddell Sea, Antarctica. In Battaglia, B., J. Valencia \& D. W. H. Dalton (eds), Antarctic Communities: Species, Structure and Survival. Cambridge University Press, Cambridge: 118-134.

Jones, D. O. B., B. J. Bett \& P. A. Tyler, 2007. Depth-related changes to density, diversity and structure of benthic megafaunal assemblages in the Fimbul ice shelf region, Weddell Sea, Antarctica. Polar Biology 30: 1579-1592.

Kaiser, S., S. N. Brandão, S. Brix, D. K. A. Barnes, D. A. Bowden, J. Ingels, F. Leese, S. Schiaparelli, C. P. Arango, R. Badhe, N. Bax, M. Blazewicz-Paskowycz, A. Brandt, N. Brenke, A. I. Catarino, B. David, C. De Ridder, P. Dubois, K. E. Ellingsen, A. G. Glover, H. J. Griffiths, J. Gutt, K. M. Halanych, C. Havermans, C. Held, D. Janussen, A.-N. Lörz, D. A. Pearce, B. Pierrat, T. Riehl, A. Rose, C. J. Sands, A. Soler-Membrives, M. Schüller, J. M. Strugnell, A. Vanreusel, G. Veit-Köhler, N. G. Wilson \& M. Yasuhara, 2013. Patterns, processes and vulnerability of Southern Ocean benthos - a decadal leap in knowledge and understanding. Marine Biology 160(9): 2295-2317.

Knox, G. \& D. Cameron, 1998. The marine fauna of the Ross Sea: polychaeta. NIWA Biodiversity Memoir 108: 1-125.

Kröger, K. \& A. A. Rowden, 2008. Polychaete assemblages of the northwestern Ross Sea shelf: worming out the environmental drivers of Antarctic macrobenthic assemblage composition. Polar Biology 31(8): 971-989.

Lenihan, H. S. \& J. S. Oliver, 1995. Anthropogenic and natural disturbances to marine benthic communities in Antarctica. Ecological Applications 5(2): 311-326.

Linse, K., H. J. Griffiths, D. K. A. Barnes, A. Brandt, N. Davey, B. David, S. DeGrave, C. d'Udekem d'Acoz, M. Eléaume, A. Glover, L. G. Hemery, C. Mah, R. Martín-Ledo, T. Munilla, M. O'Loughlin, B. Pierrat, T. Saucède, C. J. Sands, J. M. Strugnell \& P. Enderlein, 2013. The macroand megabenthic fauna on the continental shelf of the Eastern Amundsen Sea, Antarctica. Continental Shelf Research 68: 80-90.

Lörz, A.-N., S. Kaiser \& D. A. Bowden, 2013. Macrofaunal crustaceans in the benthic boundary layer from the shelf break to abyssal depths in the Ross Sea (Antarctica). Polar Biology 36: 445-451.

Lohrer, A. M., V. J. Cummings \& S. F. Thrush, 2013. Altered sea ice thickness and permanence affects benthic ecosystem functioning in coastal Antarctica. Ecosystems 16: 224-236.

MacArthur, R. H., 1972. Geographical Ecology. Harper and Row, New York.

Mitchell, J. S., 2001. NIWA Voyage report TAN0102: Antarctic hydrographic survey and scientific research by RV Tangaroa 4 February to 17 March 2001, NIWA, Wellington.

Pabis, K., J. Sicinski \& M. Krymarys, 2011. Distribution patterns in the biomass of macrozoobenthic communities in Admiralty Bay (King George Island, South Shetlands, Antarctic). Polar Biology 34: 489-500.

Pabis, K. \& J. Sicinski, 2012. Is polychaete diversity in the deep sublittoral of an Antarctic fiord related to habitat complexity? Polish Polar Research 33: 181-197.
Pena Cantero, A. L., F. Boero \& S. Piraino, 2013. Shallow-water benthic hydroids from Tethys Bay (Terra Nova Bay, Ross Sea, Antarctica). Polar Biology 36: 731-753.

Post, A. L., P. E. O'Brien, R. J. Beaman, M. J. Riddle \& L. De Santisa, 2010. Physical controls on deep-water coral communities on the George V Land slope, East Antarctica. Antarctic Science 22: 371-378.

Potthoff, M., K. Johst \& J. Gutt, 2006. How to survive as a pioneer species in the Antarctic benthos: minimum dispersal distance as a function of lifetime and disturbance. Polar Biology 29: 543-551.

Povero, P., M. Castellano, N. Ruggieri, L. S. Monticelli, V. Saggiomo, M. Chiantore, M. Guidetti \& R. Cattaneo-Vietti, 2006. Water column features and their relationship with sediments and benthic communities along the Victoria Land coast, Ross Sea, summer 2004. Antarctic Science 18: 603-613.

Rehm, P., S. Thatje, W. E. Arntz, A. Brandt \& O. Heilmayer, 2006. Distribution and composition of macrozoobenthic communities along a Victoria-Land Transect (Ross Sea, Antarctica). Polar Biology 29: 782-790.

Rehm, P., S. Thatje, U. Mühlenhardt-Siegel \& A. Brandt, 2007. Composition and distribution of the peracarid crustacean fauna along a latitudinal transect off Victoria Land (Ross Sea, Antarctica) with special emphasis on the Cumacea. Polar Biology 30: 871-881.

Rehm, P., R. A. Hooke \& S. Thatje, 2011. Macrofaunal communities on the continental shelf off Victoria Land, Ross Sea, Antarctica. Antarctic Science 23(5): 449-455.

Rhodes, R. C., H. E. Hurlburt, A. J. Wallcraft, C. N. Barron, P. J. Martin, E. J. Metzger, J. F. Shriver \& D. S. Ko, 2002. Navy real-time global modeling systems. Oceanography 15: 29-43.

Rosenzweig, M. L., 1995. Species Diversity in Space and Time. Cambridge University Press, Cambridge.

Schiaparelli, S., A.-N. Lörz \& R. Cattaneo-Vietti, 2006. Diversity and distribution of mollusc assemblages on the Victoria Land coast and the Balleny Islands, Ross Sea, Antarctica. Antarctic Science 18: 615-631.

Siciński, J., 2004. Polychaetes of Antarctic sublittoral in the proglacial zone (King George Island, South Shetland Islands). Polish Polar Research 25: 67-96.

Smale, D. A., D. K. A. Barnes \& K. P. P. Fraser, 2007. The influence of ice scour on benthic communities at 3 contrasting sites at Adelaide Island, Antarctica. Austral Ecology 32: 878-888.

Smale, D. A., D. K. A. Barnes, K. P. P. Fraser \& L. S. Peck, 2008. Benthic community response to iceberg scouring at an intensely disturbed shallow water site at Adelaide Island, Antarctica. Marine Ecology Progress Series 355: 85-94.

Smith, C. R., S. Mincks \& D. J. DeMaster, 2006. A synthesis of benthopelagic coupling on the Antarctic shelf: food banks, ecosystem inertia and global climate change. Deep Sea Research II 53: 875-894.

Teixido, N., J. Garrabou, J. Gutt \& W. E. Arntz, 2004. Recovery in Antarctic benthos after iceberg disturbance: trends in benthic composition, abundance and growth forms. Marine Ecology Progress Series 278: 1-16.

Teixidó, N., J. Garrabou, J. Gutt \& W. E. Arntz, 2007. Iceberg disturbance and successional spatial patterns: the case of 
the shelf Antarctic benthic communities. Ecosystems 10: 142-157.

Thrush, S. F. \& V. J. Cummings, 2011. Massive icebergs, alteration in primary food resources and change in benthic communities at Cape Evans, Antarctica. Marine Ecology 32: 289-299.

Thrush, S., P. Dayton, R. Cattaneo-Vietti, M. Chiantore, V. Cummings, N. Andrew, I. Hawes, S. Kim, R. Kvitek \& A.M. Schwarz, 2006. Broad-scale factors influencing the biodiversity of coastal benthic communities of the Ross Sea. Deep Sea Research II 53: 959-971.

Thrush, S. F., J. E. Hewitt, V. J. Cummings, A. Norkko \& M. Chiantore, 2010. $\beta$-diversity and species accumulation in Antarctic coastal benthos: influence of habitat, distance and productivity on ecological connectivity. PLoS ONE 5(7): e11899.

Warwick, R. M. \& K. R. Clarke, 1993. Increased variability as a symptom of stress in marine communities. Journal of Experimental Marine Biology and Ecology 172: 215-226. 